\title{
Influence of re-flooding on phytoplankton assemblages in a temperate wetland following prolonged drought
}

\author{
Luciana AVIGLIANO, ${ }^{1,2}$ Alicia VINOCUR, ${ }^{2,3}$ Griselda CHAPARRO, ${ }^{3}$ Guillermo TELL, ${ }^{4,5}$ Luz ALLENDE ${ }^{3 *}$
}

${ }^{1}$ ANPCyT (Agencia Nacional de Promoción Científica y Tecnológica), Buenos Aires; ${ }^{2}$ Departamento de Biodiversidad y Biología Experimental, Facultad de Ciencias Exactas y Naturales, Universidad de Buenos Aires, 1428 Buenos Aires; ${ }^{3}$ Departamento de Ecología, Genética y Evolución, Facultad de Ciencias Exactas y Naturales, Universidad de Buenos Aires, IEGEBA (CONICET-UBA), Int. Güiraldes 2620 C1428EHA, Buenos Aires; ${ }^{4}$ Departamento de Ecología, Genética y Evolución, Facultad de Ciencias Exactas y Naturales, Universidad de Buenos Aires, 1428 Buenos Aires; ${ }^{5}$ CONICET (Consejo Nacional de Investigaciones Científicas y Técnicas), Argentina *Corresponding author: lallende@ege.fcen.uba.ar

\begin{abstract}
Wetlands can experience drying and flooding cycles which influence the dynamics of the phytoplankton assemblages. The aim of our study was to evaluate changes in the phytoplankton structure during a drought/flood period in a warm-temperate wetland. We hypothesized that fluctuations in water level and development of macrophytes favour the development of fast-growing algae with adaptations to low light conditions. We studied algal and cyanobacterial colonization and succession in the nascent planktonic habitat in a wetland in the Southern Hemisphere (Argentina). We assessed changes in phytoplankton biovolume, chlorophyll a concentration (Chl a), richness, diversity, and evenness throughout a drought/flood period. Phytoplankton species were classified into ecological functional groups (FG). Multivariate analysis (RDA) showed that water level, conductivity and percentage macrophyte cover of the site surface (PCSS) explained the variability in the phytoplankton assemblage structure in terms of classes and FG. Particularly, FGs $T$ and $L_{M}$ responded to the changes during the droughtflood cycle, probably due to light constraints and stability of the water column induced by the development of emergent and freefloating macrophytes. Our study expands the knowledge of phytoplankton species composition and ecological FG succession under freefloating macrophyte cover in a re-flooding episode. We conclude that water depth and development of macrophytes are the key factors in shaping phytoplankton species structure in a temporary wetland.
\end{abstract}

Key words: phytoplankton, wetland, shallow lake, drought, flood, biodiversity.

Received: July 2013. Accepted: December 2013.

\section{INTRODUCTION}

There are many types of wetlands worldwide and the heterogeneity of their environments is widely known (Rojo et al., 2012). While sharing common characteristics that define them, these shallow aquatic ecosystems are naturally subjected to water-level fluctuations due to the seasonal variation of precipitation, runoff, and/or evaporation (Naselli-Flores and Barone, 2005). The hydrological variation represents an important factor in shaping wetlands. Climate change models predict increased drought episodes for many regions of the world (Jentsch et al., 2007; IPCC, 2010) as well as an enhanced frequency of extreme hydrometeorological events (Timmermann et al., 1999). Wetlands are amongst the most sensitive ecosystems (Jeppesen et al., 2007; Meerhoff et al., 2007) and may become fragmented during drought periods (Angeler et al., 2010). Recently the number of studies exploring the effects of drought on wetland communities is increasing (Bucak et al., 2012; Granado and Henry, 2014; Rojo et al., 2012; Stević et al., 2013). However, studies are still limited compared to those regarding floods and other disturbances (Lake, 2011).
Algae are key players in the physical, chemical, and biological processes that characterize most freshwater wetlands and their dynamics and composition are influenced by environmental changes triggered by water level fluctuations (Naselli-Flores and Barone, 2005, 2012). In particular, recent studies highlighted that drought events and the associated desiccation are considered as relevant factors controlling the distribution and diversity of algae in freshwater wetlands (Neustupa et al., 2011 and references therein). In this respect, some localities in subtropical wetland systems (Florida, USA) showed different species compositions as a result of differences in the length of the annual dry period; the longer dry period sites are better able to cope with non-periodic events of severe drought (Gottlieb et al., 2005). Goldsborough and Robinson (1996) proposed a conceptual model for wetland algae that includes four quasi-stable states: dry state, open state, sheltered state and lake state. The dry state is recognized and characterized by the dominance of benthic algae inhabiting the illuminated surface layers of exposed mud flats and submerged sediments. The resting stages of many aquatic organisms persist in the sediments of dry wetlands (Skinner et al., 
2001; and references therein), and their abundance and diversity reflects the capacity of an incipient wetland community to respond to re-flooding by producing colonists and resetting the processes of succession (De Stasio, 1990). Then, following flooding, dry wetlands are transformed to a state dependent on the quantity and timing of water input. If the water column is sufficiently shallow so that aquatic macrophytes can develop, the increase in substratum availability may lead to an open state wetland in which epiphytes are the predominant algal assemblage. Sheltered state is also reached at medium hydrometric levels, but it is characterized by the development of edge-vegetation, which stabilizes the water column, and the dominance of metaphyton. If water input is too rapid for macrophytes to colonize, or if vegetation is excluded by excessively deep water, phytoplankton predominates in a lake state wetland (Goldsborough and Robinson, 1996).

Plankton may be especially suitable for studying adaptive processes to environmental change at different spatial and temporal scales, because of the short generation times of many species (Leibold and Norberg, 2004). Because phytoplankton is dispersed easily, air-borne colonization or dispersal through surface connections, and also colonization through propagule banks, could mediate the strength and magnitude of local adaptation (Angeler et al., 2010). It is recognized that the phytoplankton species composition in freshwater ecosystems is influenced by the presence of aquatic macrophytes as they affect the water quality through their effects on nutrient competition, allelopathy, shading and, in the case of floating plants, anoxygenic conditions (Scheffer et al., 2003; Izaguirre et al., 2010; Naselli-Flores and Barone, 2012). Thus, hydrology-driven changes on macrophyte assemblages are expected to further impact on phytoplankton succession.

The phytoplankton community is composed of different functional associations of species that will be favoured or excluded as regards their adaptations to withstand the environmental conditions (Reynolds et al., 2002). In this sense, the functional-group model (Reynolds et al., 2002, and reviewed by Padisák et al., 2009) suggests the selection or exclusion of these adaptive features in the phytoplankton community, which are not specific to a determined phylogenetic group. Thus, the probability of the prevalence of certain functional groups, rather than species dominance, can be better narrowed down for a given set of environmental conditions. The functional group approach helps to understand why differing phytoplankton species are selected over others in an assembling community, as well as why its composition varies at both a temporal and spatial scale (Reynolds et al., 2002; Naselli-Flores and Barone, 2012; Stević et al., 2013).

In this work we aim to analyze the changes in phytoplankton structure and dynamics in a warm-temperate wetland starting from a dry state during a complete annual drought/flood cycle. We explore the response of the phytoplankton species composition and functional-group assemblage to the re-flooding of the basin. We hypothesize that rapid changes in water level and macrophyte cover (emergent and/or free floating) affect the phytoplankton composition and favour functional groups represented by small fast-growing algae with adaptations to low light conditions. As well, the persistence of a free-floating macrophyte cover favours algae with adaptations to withstand the physical stability of the water column imposed by the presence of macrophytes, and the low light conditions encountered beneath the coverage.

\section{METHODS}

\section{Study site}

The Reserva Ecológica Costanera Sur (RECS hereafter) $\left(34^{\circ} 36^{\prime} \mathrm{S}-58^{\circ} 21^{\prime} \mathrm{W}\right)$ is located on the east of Buenos Aires city (Argentina) (Fig. 1). This area was created in 1978, by reclaiming land from the river; by ground-filling with sediments from the Rio de la Plata. Three shallow water bodies were created within the reserve, delimited by constructed levees without river connection. These management efforts continued until 1984 when it was declared a natural park and ecological reserve in 1986. Despite its anthropogenic origin, RECS can be considered a wetland following the criteria of the Wetland Convention (Davis et al., 1996) and since 2005, the area was included in the list of Wetlands of International Importance of the International Convention on Wetlands. This wetland is in the temperate region of the Southern Hemisphere, with mean annual precipitation of 800-1000 $\mathrm{mm}$ (Servicio Meteorológico Nacional, 2012). In recent years, the area has been influenced by increased frequency of extreme hydrometeorological events such as El Niño Southern Oscillation (ENSO), measured by the Southern Oscillation Index (SOI). When the SOI is strongly negative (El Niño) intense rains and mayor flooding may occur in this area and, contrarily, when SOI is positive (La Niña) severe droughts may occur.

In this work, we studied one of the shallow lakes of RECS, Los Coipos Lake. Since it was built until 2008, the water level of this shallow lake has fluctuated seasonally, generally increasing in autumn (maximum depth: $1.5 \mathrm{~m}$ ) and decreasing in summer (Zapata, personal communication). The summer season is critical due to the high temperatures that increase evaporation and that can result in drying out of the lake. The hydrological behavior of recent years characterizes Los Coipos shallow lake as a temporary water body that alternates between drougth and flooded states. This shallow lake was completely dry in summer 2008, its watershed was colonized by grassland until autumn 2009 when it was subjected to re-flooding. During 2007-2008 the region was under a moderate effect 
a)

c)

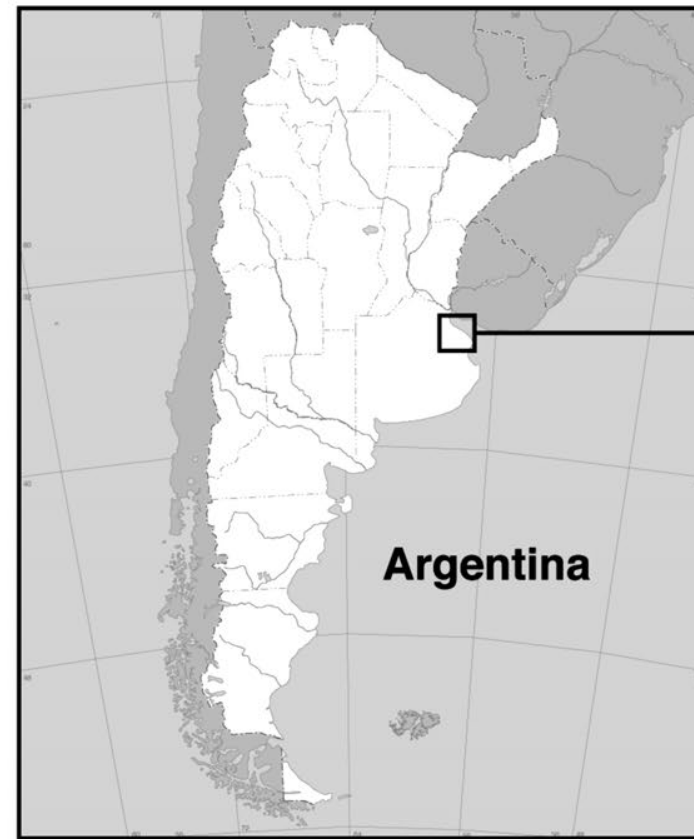

b)

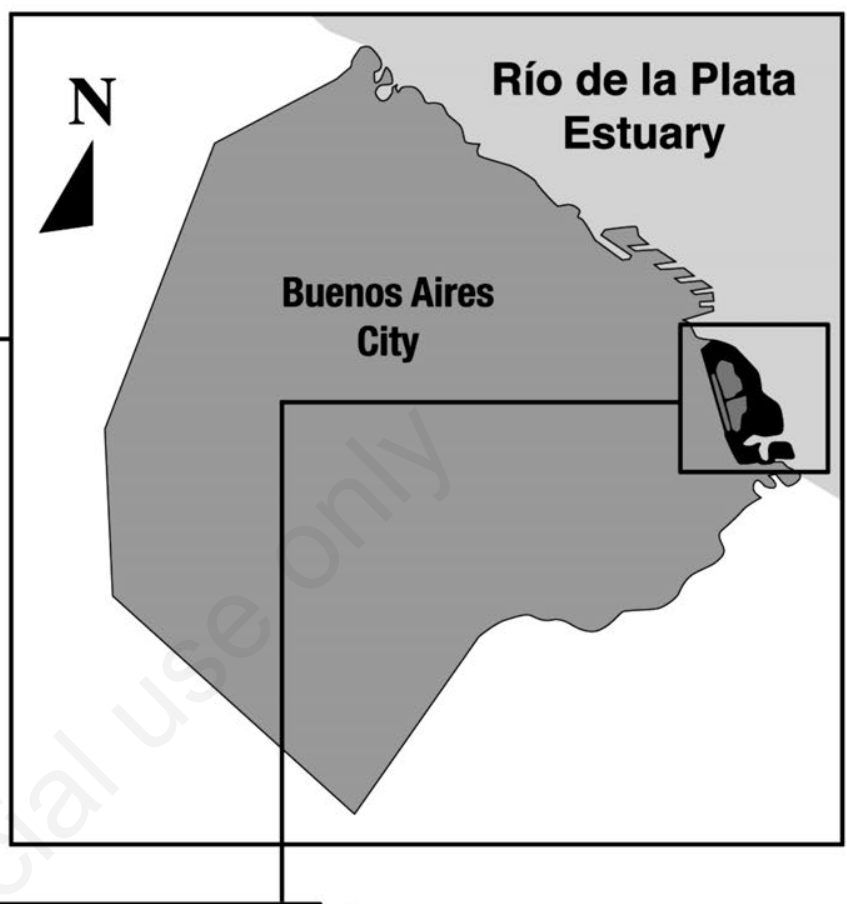

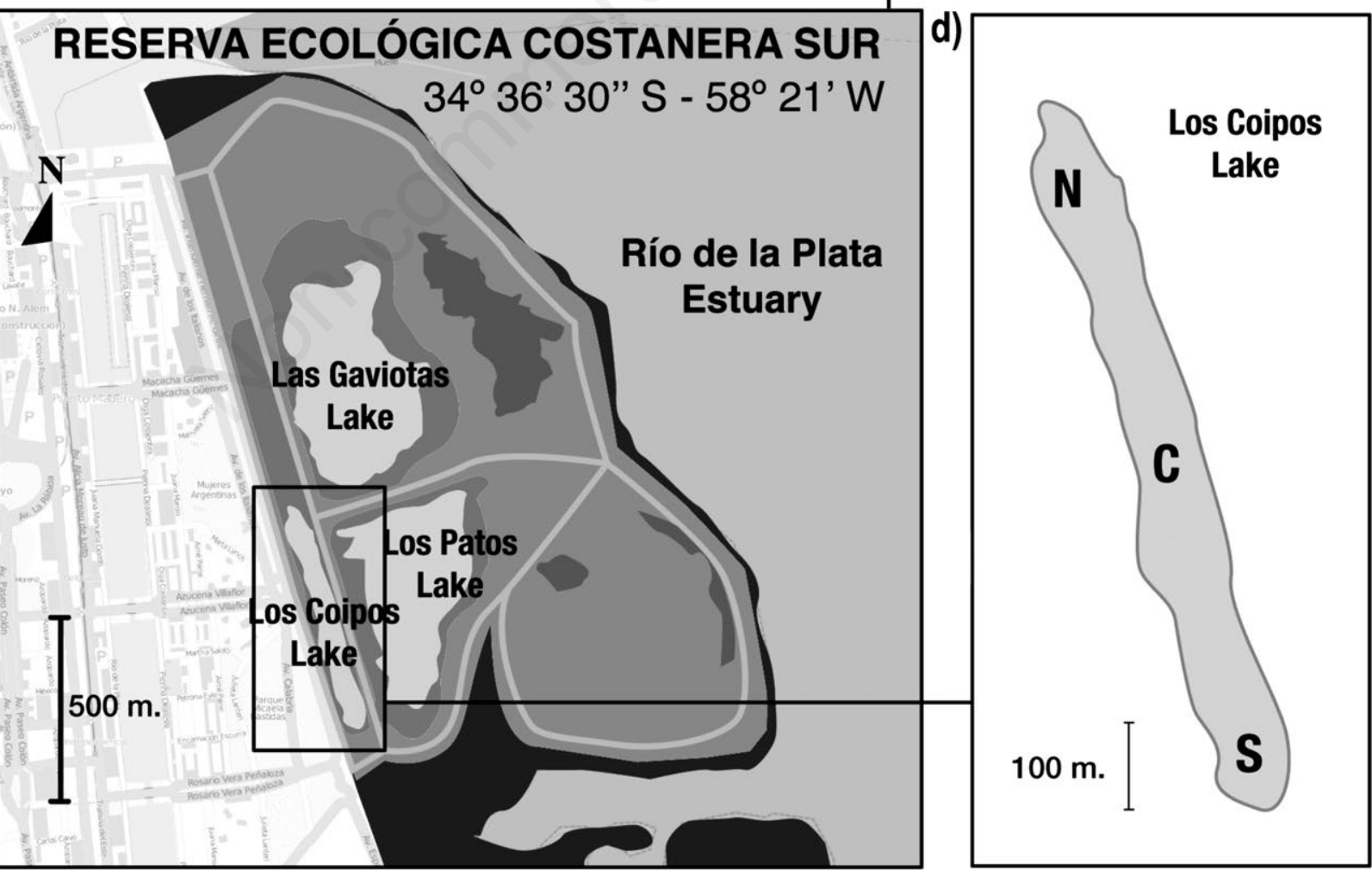

Fig. 1. a) Republic of Argentina map. b) Buenos Aires city map. c) Reserva Ecológica Costanera Sur (RECS) scheme, with Los Coipos Lake on the box. Modified from http://www.buenosaires.gov.ar/areas/med_ambiente/reserva/mapa.php. d) Los Coipos Lake indicating the sampling sites: N, site North; C, site Central; S, site South. 
of possitive SOI (La Niña) and in April 2009 a strong negative SOI (El Niño) effect started. The study was carried out throughout this El Niño period from August 2009, when the bassin of the shallow lake started to be refilled, until August 2010 when it ended-up completely covered by a dense macrophyte cover.

\section{Sampling methodology}

To test our hypotheses typical limnological variables (both biotic and abiotic) were measured during a drought/flood period (August 2009-August 2010) starting from a dry state (Goldsborough and Robinson, 1996). Water samples for physical, chemical and biological analyses were collected from Los Coipos Lake at three sites: South (S), Central (C) and North (N), coinciding with previously studied sites (Fazio and O'Farrell, 2005). Each of the three sites was sampled on 14 occasions, resulting in a total of 42 samples. Initially, three isolated ponds located within the watershed of the dried shallow lake were sampled fortnightly (initial period hereafter: 19-Aug-09, 2-Sep-09, 15-Sep-09); and then, when the three ponds connected together into a single and continuous water body, approximately at month intervals (reflooding period herein after: 28-Sep-09, 19-Oct-09, 9-Nov-09, 30-Nov-09, 21-Dec-09, 25-Jan-10, 8-Mar-10, 5-Apr-10, 3-May-10, 29-Jun-10, 19-Aug-10).

At all sampling dates we recorded the vegetation type (if present) in each of the three sampling sites. We also estimated the percentage cover of the site surface (PCSS) by emergent and free floating macrophytes using four categories: no vegetation, up to $25 \%, 26-75 \%$, and $76-100 \%$. To study the evolution of the shallow lake during the drought/flood interval 2009-2010, Landsat 5TM images (Path 225, Row 84) that were available for the period were used. We obtained four images characteristic of four well defined scenarios: February 4, 2009 (initial dry state) which persisted until the re-flooding on August 2010; October 2, 2009 (incipient formation of a continuous water body); January 22, 2010 (sharp water level decrease); September 19, 2010 (shallow lake with complete surface coverage by emergent and floating macrophytes). A sub-area covering the study site was extracted and geometric correction was performed using well distributed Ground Control Points, with a positional accuracy of \pm 1 pixels. A radiometric correction was conducted with the Rayleigh dispersion model (Stumpf, 1992). The total lake area was determined as the largest area found during high waters. In order to estimate the percent cover of macrophytes in the lake an unsupervised classification was performed based on ISODATA clustering with a variability threshold of $98 \%$ in each image. We used the signature editor in ERDAS Imagine to extract spectral data from the image for the classes (vegetation and water). The classification of the satellite data and the analysis of spectral signatures together with the in situ observations allowed us to characterize the scenarios at the whole lake level. Image processing was conducted using ERDAS Imagine 9.1 software.

\section{Physical and chemical analyses}

Dissolved oxygen (DO) concentration, water temperature, $\mathrm{pH}$, and conductivity were measured in situ with Hanna HI8314 and Hanna HI8033 portable electronic sensors (Hanna Instruments, Smithfield, RI, USA) and the transparency was estimated using a Secchi disk. The water depth of each site was measured with a meter stick. Water samples were collected for the determination of the main dissolved nutrients for algal and cyanobacterial growth; soluble reactive phosphorus (SRP), ammonium $\left(\mathrm{N}^{-\mathrm{NH}_{4}}\right)$ and nitrates+nitrites $\left(\mathrm{N}^{-\mathrm{NO}_{3}}+\mathrm{N}-\mathrm{NO}_{2}\right)$. The concentrations of these nutrients were determined using a $\mathrm{HACH}^{\circledR} \mathrm{DR} / 2010$ $\left(\mathrm{HACH}^{\circledR}\right.$ Company, USA) spectrophotometer and the corresponding kits of $\mathrm{HACH}^{\circledR}$ reagents (detection limits: 0.001-2.500 mg L-1 for SRP; 0.001-2.500 mg L-1 for $\mathrm{N}-\mathrm{NH}_{4} ; 0.01-0.50 \mathrm{mg} \mathrm{L}^{-1}$ (low range) and 0.3-30.0 $\mathrm{mg} \mathrm{L}^{-1}$ (high range) for $\mathrm{N}^{-\mathrm{NO}_{3}}+\mathrm{N}-\mathrm{NO}_{2}$ ). Samples for nutrient analysis were filtered through Whatman ${ }^{\circledR} \mathrm{GF} / \mathrm{F}$ filters. SRP concentration was estimated by the ascorbic acid method, the concentration of $\mathrm{N}^{-\mathrm{NH}_{4}}$ was determined by the indophenol-blue method, and that of $\mathrm{N}-\mathrm{NO}_{3}+\mathrm{N}-\mathrm{NO}_{2}$ was estimated by the cadmium reduction method (APHA, 2005). Dissolved inorganic nitrogen (DIN) represents the sum of $\mathrm{N}-\mathrm{NH}_{4}+\mathrm{N}-\mathrm{NO}_{3}+\mathrm{N}-\mathrm{NO}_{2}$. In addition, water samples were filtered with Whatman ${ }^{\circledR} \mathrm{GF} / \mathrm{C}$ in the laboratory in order to determine the concentration of suspended solids (SS) by weighing the dry residue at $103^{\circ} \mathrm{C}$ (APHA, 2005).

\section{Biological analyses}

Samples for the estimation of phytoplankton chlorophyll $a$ concentration ( $\mathrm{Chl} a$ ), and for the qualitative and quantitative analyses of phytoplankton were obtained in PVC flasks. Chl $a$ was estimated spectrophotometrically using hot ethanol $\left(60-70^{\circ} \mathrm{C}\right)$ extraction (Lorenzen, 1967; Nusch, 1980). Qualitative cyanobacterial and algal samples were obtained with a $15 \mu \mathrm{m}$ pore net, a sub-sample was fixed in $4 \%$ formalin and a second sub-sample was used for in vivo taxonomical identification using a light microscope $\left(\right.$ Zeiss $\left.^{\circledR}\right)$ at X1000 magnification and up-to date phycological references such as Komárek and Anagnostidis (1999), Komárek and Anagnostidis (2005) for cyanobacteria; Hüber-Pestalozzi (1941) and Starmach (1985) for Chrysophyceae; Javornicky (2003) for Cryptophyceae; Krammer and Lange-Bertalot (1986, 1988, 1991a,b), Lange-Bertalot (2001), Metzeltin and GarcíaRodriguez (2003) and Zalocar de Domitrovic and Maidana (1997) for Bacillariophyceae; Komárek and Fott (1983) for Chlorococcales; Prescott et al. (1975, 1977, 1981) for Zygnematophyceae; Ettl (1978) for Tribo- 
phyceae; Tell and Conforti (1986) for Euglenophyceae.

Quantitative $(>2 \mu \mathrm{m})$ phytoplankton samples were fixed with $1 \%$ acidified Lugol's iodine, and those for the quantification of picophytoplankton $(0.2-2 \mu \mathrm{m})$ were preserved with $2 \%$ ice-cold glutaraldehyde. In order to estimate the abundance of each of the phytoplankton size-fractions, two sub-samples were counted and averaged for each sampling date and site. The counts of the $>2 \mu \mathrm{m}$ phytoplankton fraction were carried out to species level whenever possible, using an inverted microscope $\left(\right.$ Zeiss $^{\mathbb{B}}$ ) following the Utermöhl (1958) technique at X 400 magnification on chambers of 5 or $10 \mathrm{cc}$ after at least $24 \mathrm{~h}$ sedimentation. Counting errors were estimated according to Venrick (1978), accepting a maximum of $20 \%$ for the most abundant species. Algae were classified in the differing classes and according to the functional groups (FG) proposed by Reynolds et al. (2002) and reviewed by Padisák et al. (2009). Biovolumes of all algal species were calculated following Hillebrand et al. (1999) and Sun and Liu (2003). Then, considering the abundances and the calculated biovolume for each species, we estimated the total biovolumes of each of the algal classes and cyanobacteria, as well as those of each of the FG.

Picophytoplankton fraction was counted from the fluorescence given off by photosynthetic pigments following Kemp et al. (1999); $2 \mathrm{~mL}$ sub-samples were filtered through $0.2 \mu \mathrm{m}$ pore sized black polycarbonate filters. Each filter was examined for pigment autofluorescence with a Zeiss $^{\circledR}$ Axioplan microscope equipped with an HBO 50W lamp, and a filter set for blue light excitation (BP 450-490 $\mathrm{nm}$, FT $510 \mathrm{~nm}$, LP $520 \mathrm{~nm}$ ) and green light excitation (BP $546 \mathrm{~nm}$, FT $580 \mathrm{~nm}$, LP $590 \mathrm{~nm}$ ) were used in order to identify picoeukaryotic algae and picocyanobacteria, respectively. A minimum of 400 cells were counted (corresponding to at least 20 fields of view) at X1000 magnification, accepting a maximum of $15 \%$ error.

\section{Data analyses}

We estimated different attributes of phytoplankton assemblage: species richness, diversity (Shannon-Wiener) (Magurran, 1988) and evenness (Pielou, 1966) for each sample site and date (a total of 42 samples) in terms of biovolume. Total species richness of Los Coipos Lake was calculated as total number of species encountered in water column, considering both the qualitative and quantitative study of $>2 \mu \mathrm{m}$ phytoplankton, throughout the study period. Average species richness, diversity and evenness were calculated as the mean value of the three sites (S, C and $\mathrm{N}$ ) per sampling date for each variable.

We performed descriptive statistical analysis of the physical, chemical and biological variables (SPSS Statistics 17.0 - StatSoft, USA). Non-parametric correlations were performed with Spearman's Rho coefficient among the abiotic variables, abiotic parameters $v s$ algal classes, abiotic variables $v s$ biovolumes of algal clases or biovolumes of FG. We calculated Stander's similarity index SIMI (Elber and Schanz, 1989), in order to compare, in pairs, phytoplankton community structure of different sites in temporal succession using abundance values. This index ranges between $0-1$, with 1 representing the highest similarity between a pair of communities. Direct ordination analyses were used to assess for significant relationships between environmental variables and phytoplankton species biovolume, including species that represented more than $5 \%$ of the total $>2 \mu \mathrm{m}$ phytoplankton biovolume. Previously, we performed a Detrended Correspondence Analyses (DCA) and, as data showed a linear response, we applied a Redundancy Analysis (RDA) in order to select the minimum number of variables that explained the highest variability in phytoplankton composition. The biological data were log-transformed. All environmental parameters that were not highly correlated $(r>0.90)$ were included in the analysis: water depth, conductivity, pH, DIN, SRP, PCSS, presence/absence of emergent macrophytes (EM), and presence/absence of free-floating macrophytes (FFM). PCSS was considered as a categorical variable: 0 , no vegetation; 1 , up to $25 \% ; 2,26-75 \% ; 3,76-100 \%$. Significance of ordination axes was assessed by Monte Carlo permutation test (499 permutations). Relative contribution of each of environmental variables to the ordination axes was evaluated by intraset correlations. Multivariate analyses were performed using CANOCO program for Windows 4.5 (Canonical Community Ordination) (ter Braak and Smilauer, 2002).

\section{RESULTS}

Los Coipos Lake was characterized by wide waterlevel fluctuations from its initial dry state (December 2008-August 2009) and as it was subjected to re-flooding during the drought/flood period 2009-2010. In February 4 2009, the satellite image (Fig. 2a) and the spectral signatures of classes derived from the classification technique showed that the entire lake area was covered by vegetation (reflectance peaks at green and near infrared bands), mostly comprised by grassland that colonized when the lake had no surface water. This image coincides with the dry period that occurred before our study. With the onset of re-flooding in August 2009, the lake gradually changed: on October 2, 2009 (Fig. 2b), 55\% of the lake area, comprising mainly the central region, was represented by open-water (low reflectance in visible region of the spectra and no reflectance in near and far infrared regions). Interestingly, within this area, aquatic vegetation cover (Typha latifolia) tended to increase towards the littoral zone. Moreover, the edge of the lake was covered by dry vegetation, as depicted by the higher reflectance in the far infrared region of the spectral signature. This dry vegetation represents the remnant grassland, which de- 
cayed with the increase in water level and was gradually replaced by aquatic plants. In January 22, 2010 (Fig. 2c), the central open-water region comprised only $18 \%$ of lake area, as the littoral aquatic vegetated area increased to 63\%, including Azolla filiculoides and Pistia striatotes. In early summer (December 2009-January 2010) the lake decreased in its water depth (Fig. 3) due to high water temperatures and low precipitation measured in that summer period. During this period, the increased concentration of Chl $a$ in the water column was evidenced by lower reflectance in the blue region and a small peak in the near infrared region of the spectra. Both northern and eastern edges were still covered by dry grassland vegetation. Regarding the final state, in September 19, 2010 (Fig. 2d)

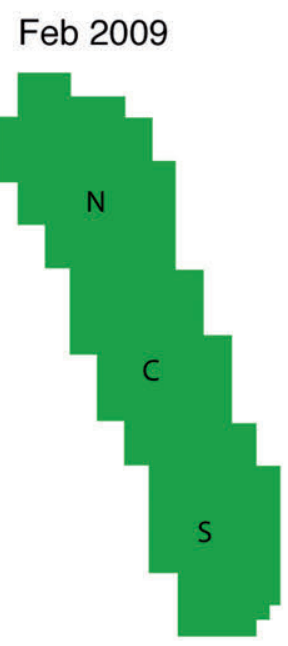

a)

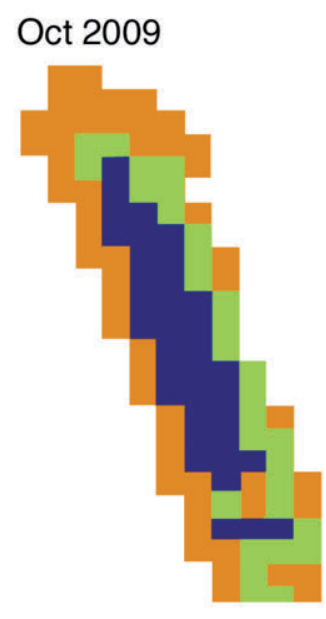

b)

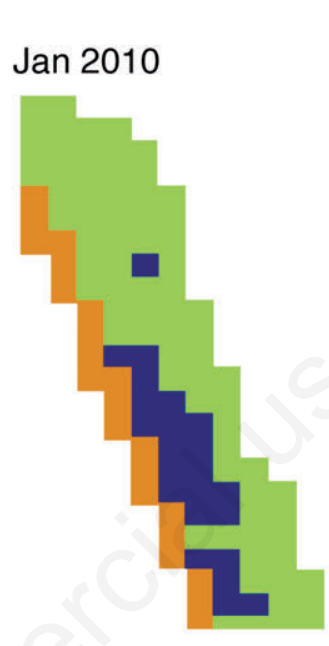

c)

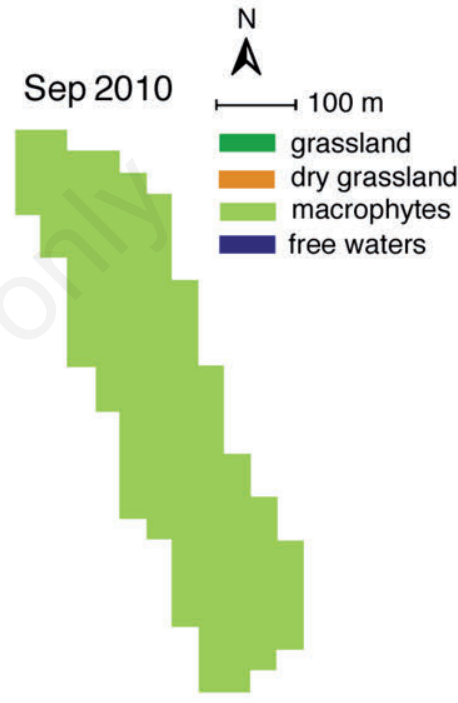

d)

Fig. 2. Thematic maps representing the surface coverage of the different landscape elements from Los Coipos Lake obtained from Landsat 5TM images available for the study period. N, site North; C, site Central; S, site South. a) Feb 2009. b) Oct 2009. c) Jan 2010. d) Sep 2010.

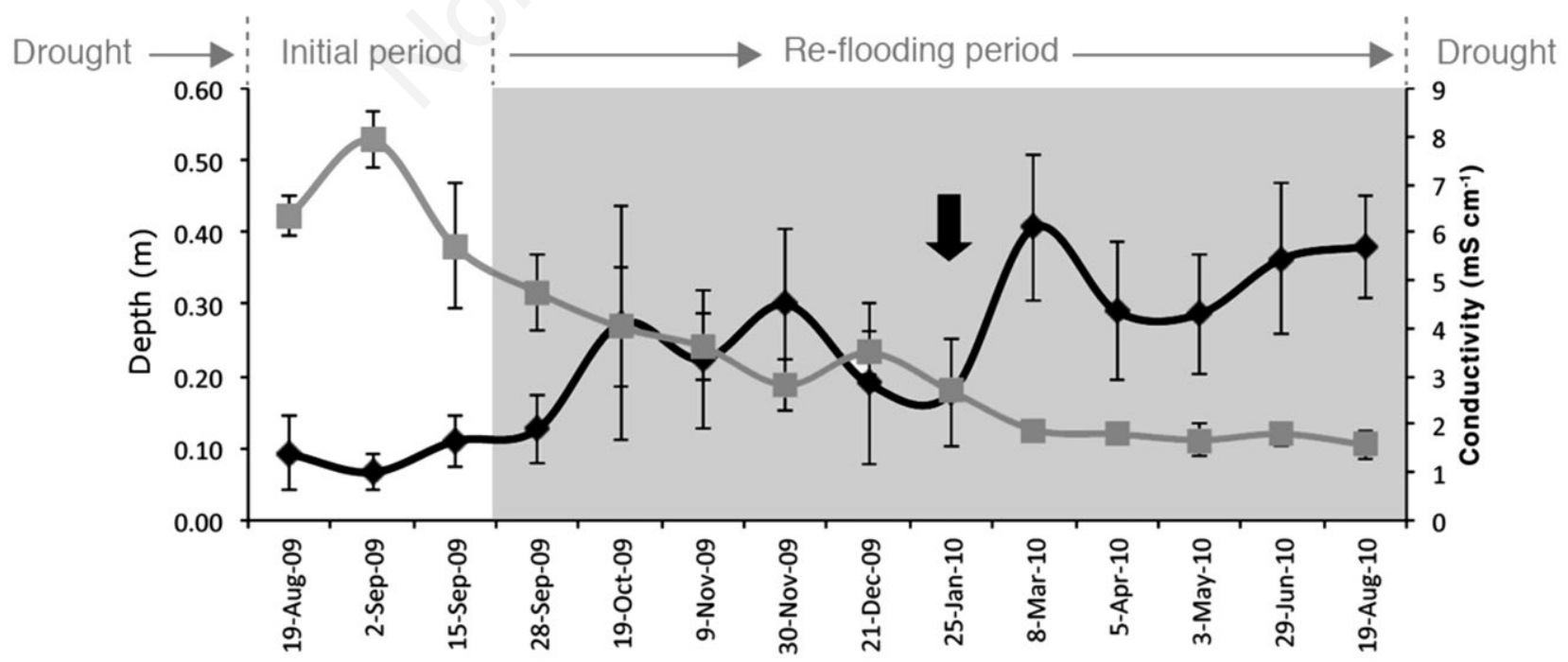

Fig. 3. Average temporal fluctuations of water depth (black) and conductivity (grey) in Los Coipos Lake during the study period (August 2009-August 2010). The shaded background indicates the formation of a continuous shallow lake. The bars indicate \pm 1 standard deviation. 
no open-water area was detected for the lake surface; spectral signatures denote that $100 \%$ of the area was covered by aquatic vegetation. Particularly, the central zone was covered by free-floating plants mainly Azolla filiculoides (greater reflectance peaks in red and near infrared regions), whereas littoral areas were covered by both freefloating and emergent macrophytes (Azolla filiculoides, Pistia striatotes and Typha latifolia).

\section{Physical and chemical properties}

Ours results showed marked differences in physical and chemical characteristics of the three studied sites in Los Coipos Lake throughout an annual drought/flood period (Tab. 1). Initially, the three sites consisted of isolated pools, with depths not exceeding $0.15 \mathrm{~m}$ (Fig. 3) until early spring (four weeks later) when the three pools connected together into a single shallow water body. Throughout the study, water depth was similar at all three sites. Conductivity was high $\left(8.56 \mathrm{mS} \mathrm{cm}^{-1}\right)$ at the beginning of the study (August-September 2009) and decreased with increasing water depth (Fig. 3). Average $\mathrm{pH}$ values (Tab. 1) were minimum in winter (June 2010) and maximum in the summer (January 2010). A positive correlation between this variable and temperature $(n=42, r=0.54$, $\mathrm{P}<0.0001$ ) was encountered. DO concentrations (Tab. 1) showed large fluctuations in temporal scale, which did not respond to a seasonal pattern. Minimum values were recorded when the shallow lake surface was covered by free-floating macrophytes (April-August 2010). We found a positive correlation between this variable and $\mathrm{pH}(\mathrm{n}=42$; $\mathrm{r}=0.52 ; \mathrm{P}<0.0001$ ). The SS concentrations (Tab. 1) were variable throughout the study; the highest levels were found when the water depth was low. In the absence of free-floating macrophytes, Secchi disk depth reached the bottom of the lake.

The concentration of dissolved nutrients (SRP, $\mathrm{N}-\mathrm{NO}_{3}+\mathrm{N}-\mathrm{NO}_{2}$ and $\mathrm{N}-\mathrm{NH}_{4}$ ) showed differences among the sites during the study period, presenting a relatively wide range of values (Tab. 1). The highest concentrations of $\mathrm{N}^{-\mathrm{NH}_{4}}$ values were found when the lake surface was totally covered with floating macrophytes. DIN ranged from 0.02 to $1.30 \mathrm{mg} \mathrm{L}^{-1}$, and the lowest values were found at the beginning and at the end of the study period. The proportions of $\mathrm{N}-\mathrm{NH}_{4} / \mathrm{N}-\mathrm{NO}_{3}+\mathrm{N}-\mathrm{NO}_{2}$ were variable and at the end of the study the ratio was highest.

\section{Algal assemblage attributes}

A high positive correlation between abundance and biovolume $(\mathrm{n}=42, \mathrm{r}=0.87, \mathrm{P}<0.0001)$ was encountered for all algal classes, except Chlorophyceae $(n=42, r=0.56$, $\mathrm{P}<0.0001)$ and cyanobacteria $(\mathrm{n}=42, \mathrm{r}=0.74, \mathrm{P}<0.0001)$. Fluctuations were detected in picophytoplankton, $>2 \mu \mathrm{m}$ phytoplankton species diversity, species richness and evenness of phytoplankton assemblage of Los Coipos Lake throughout the drought/flood period 2009-2010 (Tab. 2). Phytoplankton Chl $a$ concentration and $>2 \mu \mathrm{m}$ phytoplankton showed marked variations (Fig. 4). The highest values of Chl $a$ did not always coincide with the $>2 \mu \mathrm{m}$ phytoplankton biovolume. The picophytoplankton composition consisted of phycocyanin-rich picocyanobacteria $\left(0.97-5.3 \mathrm{~mm}^{3} \mathrm{~L}^{-1}\right)$ that dominated the picoeukaryotic algae $\left(<1.2 \mathrm{~mm}^{3} \mathrm{~L}^{-1}\right)$ in all samples. Within the larger phytoplankton $>2 \mu \mathrm{m}$ fraction, we recorded a total of 191 algal species and 44 cyanobacteria when adding up all the taxa encountered in the qualitative and the quantitative analyses. The floristic list of our study shows 235 species (Supplementary Tab. 1). Of those, 140 species were present in the quantitative samples belonging to eight algal classes and cyanobacteria. Algal species richness was similar in the three sites and the lowest values were recorded at the beginning and the end of this study (Tab. 2). Minimum evenness was found at the beginning of the study ( 0.14 on site $C$ in August 2009), and the maximum was recorded with the formation of the lake (0.82 on Novem-

Tab. 1. Descriptive statistics of the physical and chemical parameters measured in Los Coipos Lake (annual averages) during the study period (August 2009-August 2010). Mean and range (min-max).

\begin{tabular}{llccc}
\hline Variable & $\mathrm{N}$ & Site $\mathrm{S}$ & Site C & Site N \\
\hline Depth $(\mathrm{m})$ & 14 & $0.18(0.07-0.32)$ & $0.33(0.09-0.52)$ & $0.20(0.04-0.38)$ \\
Conductivity $\left(\mathrm{mS} \mathrm{cm}^{-1}\right)$ & 14 & $3.73(1.30-7.40)$ & $3.79(1.52-7.79)$ & $3.21(1.43-8.56)$ \\
Temperature $\left({ }^{\circ} \mathrm{C}\right)$ & 14 & $18.40(10.40-28.00)$ & $17.84(8.70-27.00)$ & $16.72(7.20-27.50)$ \\
pH & 14 & $7.52(6.03-9.57)$ & $7.89(5.23-10.45)$ & $7.90(4.92-9.83)$ \\
$\mathrm{DO}(\mathrm{ppm})$ & 14 & $7.80(1.64-15.51)$ & $7.20(1.35-12.99)$ & $6.68(0.22-11.71)$ \\
$\mathrm{SS}\left(\mathrm{mg} \mathrm{L}^{-1}\right)$ & 14 & $26.38(8.50-49)$ & $14.24(4.00-29.00)$ & $53.48(6.00-62.80)$ \\
$\mathrm{SRP}\left(\mathrm{mg} \mathrm{L}^{-1}\right)$ & 14 & $0.09(0.02-0.18)$ & $0.07(0.03-0.11)$ & $0.12(0.03-0.24)$ \\
$\mathrm{N}_{-} \mathrm{NH}_{4}\left(\mathrm{mg} \mathrm{L}^{-1}\right)$ & & $0.04(0-0.10)(\mathrm{N}=14)$ & $0.03(\mathrm{nd}-0.09)(\mathrm{N}=13)$ & $0.07(0-0.21)(\mathrm{N}=14)$ \\
$\mathrm{N}-\mathrm{NO}_{3}+\mathrm{N}-N O_{2}\left(\mathrm{mg} \mathrm{L}^{-1}\right)$ & & $0.49(0.01-1.30)(\mathrm{N}=14)$ & $0.51(\mathrm{nd}-0.80)(\mathrm{N}=13)$ & $0.34(\mathrm{nd}-0.70)(\mathrm{N}=11)$ \\
DIN $\left(\mathrm{mg} \mathrm{L}^{-1}\right)$ & 14 & $0.56(0.20-1.30)$ & $0.50(0.03-0.83)$ & $0.41(0.02-0.91)$ \\
\hline
\end{tabular}

$N$, number of samples; Site S, site South; Site C, site Central; Site N, site North; DO, dissolved oxygen concentration; SS, suspended solids; SRP, soluble reactive phosphorus; $\mathrm{NH}_{4}$, ammonium; $\mathrm{NO}_{3}+\mathrm{NO}_{2}$, nitrates + nitrites; DIN, dissolved inorganic nitrogen; nd, not detectable. 
ber 2009) and with the development of a profuse freefloating macrophyte cover (0.80 on June 2010). Diversity (Shannon-Wiener) values ranged between 0.34 and 2.63. The characteristic habitat of the cyanobacteria and algae encountered in the water column fluctuated according to water depth of the lake (Fig. 5 a,b,c). We observed a relative high algal biovolume, mainly represented by benthic species, during the initial period when water depth was low and the lake comprised isolated ponds. The relative importance of benthic algae decreased with increasing depths. In the beginning of the re-flooding period (late September-December 2009) we observed an enhanced development of epiphytic algae and cyanobacteria. The relative contribution of different algal classes and cyanobacteria to total $>2 \mu \mathrm{m}$ phytoplankton biovolume also fluctuated throughout the studied period (Fig. 5 d,e,f). Initially, the three sites differed in their algal class and cyanobacterial composition being dominated by Euglenophyceae at site $\mathrm{S}$ (negative correlation with conductivity: $\mathrm{n}=42, \mathrm{r}=-0.46, \mathrm{P}<0.002$ ) (Fig. 5d), Dinophyceae at site $\mathrm{C}$ (Fig. 5e) Bacillariophyceae and Chlorophyceae at site $\mathrm{N}$ (Fig. 5f). In all three sites, Bacillariophyceae increased their relative abundance until the formation of the continuous shallow lake and then; in the re-flooding period, their relative contribution was variable, though a decreasing pattern was observed as the lake was covered with macrophytes (negative correlation with EM emergent macrophytes: $\mathrm{n}=42, \mathrm{r}=-0.47, \mathrm{P}<0.002$ ). Chlorophyceae and cyanobacteria were present throughout the study, with variable contributions. A positive correlation between Cyanobacteria and SRP was encountered $(n=42, r=0.44$, $\mathrm{P}<0.004$ ). At the end of the study, Euglenophyceae and
Cryptophyceae were co-dominant at site S (Fig. 5d) Chlorophyceae and Cryptophyceae were also co-dominant at site $\mathrm{C}$ (Fig. 5e), while Cyanobacteria were dominant at site N (Fig. 5f). Furthermore, Euglenophyceae and Cryptophyceae showed a positive correlation with freefloating macrophytes cover FFM ( $\mathrm{n}=42, \mathrm{r}=0.50, \mathrm{P}<0.001$ and $\mathrm{n}=42, \mathrm{r}=0.55, \mathrm{P}<0.0001$, respectively).

As regards functional group classification, 12 of the 39 FG proposed were encountered in a proportion that exceeded $2 \%$ of the total biovolume, with variable dominance throughout the drought/flood cycle (Tab. 3). Initial proportions of FGs of the three sites were different and dominated by W1 (Euglena caudata) and Y (Cryptomonas cf. obovata); $\mathrm{L}_{\mathrm{O}}$ (Peridinium sp.); $\mathrm{C}$ and X1 (Stephanocyclus meneghiniana and Chlamydomonas spp.) for sites S, C and $\mathrm{N}$ respectively. In the re-flooding period, when the three pools were connected in a continuous water body, we observed a different contribution of FGs to the phytoplankton community. Assemblages mainly represented were W2, Y, $\mathrm{D}, \mathrm{T}, \mathrm{W} 1, \mathrm{M}, \mathrm{L}_{\mathrm{M}}$ and $\mathrm{C}$. Towards the end of the study period when the whole shallow lake was covered by a dense freefloating plant cover (mainly Azolla filiculoides), sites S and $\mathrm{C}$ were similar in terms of the proportion of co-dominants W1 and Y, whereas at site N, $\mathrm{L}_{\mathrm{M}}$ was clearly dominant. Significant correlation coefficients were found between $\mathrm{D}$, $\mathrm{W} 1$, W2 and $\mathrm{Y}$ vs FFM $(\mathrm{n}=42, \mathrm{r}=0.51, \mathrm{P}<0.001 ; \mathrm{n}=42$, $\mathrm{r}=0.43, \mathrm{P}<0.005 ; \mathrm{n}=42, \mathrm{r}=0.49, \mathrm{P}<0.001$ and $\mathrm{n}=42, \mathrm{r}=0.55$, $\mathrm{P}<0.0001$ respectively); whereas $\mathrm{W} 1$ showed a negative correlation with conductivity $(\mathrm{n}=42, \mathrm{r}=-0.40, \mathrm{P}<0.008)$, W2 with $\mathrm{pH}(\mathrm{n}=42, \mathrm{r}=-0.42, \mathrm{P}<0.06)$ and $\mathrm{T}_{\mathrm{B}}$ with water depth $(\mathrm{n}=42, \mathrm{r}=-0.4, \mathrm{P}<0.009)$. Analysis of the similarity of the community structure by means of the SIMI index, revealed

Tab. 2. Ranges of biovolume for different phytoplankton attributes recorded in Los Coipos Lake, throughout the study period (August 2009-August 2010). Range (min-max).

\begin{tabular}{|c|c|c|c|c|}
\hline Variable & $\mathrm{N}$ & Site $\mathrm{S}$ & Site C & Site $N$ \\
\hline Chl $a\left(\mu \mathrm{g} \mathrm{L}^{-1}\right)$ & 14 & $(1.08-67.93)$ & $(1.63-81.87)$ & $(0-84.48)(\mathrm{N}=13)$ \\
\hline Picophytoplankton $\left(\mathrm{mm}^{3} \mathrm{~L}^{-1}\right)$ & 14 & $(1.48-4.33)$ & $(1.17-4.38)$ & $(1.96-6.55)$ \\
\hline Picocyanobacteria $\left(\mathrm{mm}^{3} \mathrm{~L}^{-1}\right)$ & 14 & $(1.25-3.20)$ & $(0.97-4.01)$ & $(1.75-5.33)$ \\
\hline Picoeukaryotic algae $\left(\mathrm{mm}^{3} \mathrm{~L}^{-1}\right)$ & 14 & $(0.21-1.13)$ & $(0.14-0.92)$ & $(0.19-1.22)$ \\
\hline Phytoplankton $>2 \mu \mathrm{m}\left(\mathrm{mm}^{3} \mathrm{~L}^{-1}\right)$ & 14 & $(0.41-45.20)$ & $(0.57-25.79)$ & $(0.45-35.07)$ \\
\hline Cyanobacteria $\left(\mathrm{mm}^{3} \mathrm{~L}^{-1}\right)$ & 14 & $(0-0.63)$ & $(0-0.60)$ & $(0.02-21.59)$ \\
\hline Bacillariophyceae $\left(\mathrm{mm}^{3} \mathrm{~L}^{-1}\right)$ & 14 & $(0.08-7.61)$ & $(0.01-1.93)$ & $(0.05-8.97)$ \\
\hline Chlorophyceae $\left(\mathrm{mm}^{3} \mathrm{~L}^{-1}\right)$ & 14 & $(0-1.18)$ & $(0.03-5.03)$ & $(0.04-3.85)$ \\
\hline Chrysophyceae $\left(\mathrm{mm}^{3} \mathrm{~L}^{-1}\right)$ & 14 & $(0-3.67)$ & $(0-0.15)$ & $(0-0.16)$ \\
\hline Cryptophyceae $\left(\mathrm{mm}^{3} \mathrm{~L}^{-1}\right)$ & 14 & $(0-11.38)$ & $(0-2.59)$ & $(0-0.26)$ \\
\hline Dinophyceae $\left(\mathrm{mm}^{3} \mathrm{~L}^{-1}\right)$ & 14 & $(0-0.34)$ & $(0-24.02)$ & Not found \\
\hline Euglenophyceae $\left(\mathrm{mm}^{3} \mathrm{~L}^{-1}\right)$ & 14 & $(0-30.80)$ & $(0-2.12)$ & $(0-3.38)$ \\
\hline Tribophyceae $\left(\mathrm{mm}^{3} \mathrm{~L}^{-1}\right)$ & 14 & $(0-0.29)$ & Not found & Not found \\
\hline Zygnematophyceae $\left(\mathrm{mm}^{3} \mathrm{~L}^{-1}\right)$ & 14 & $(0-0.03)$ & $(0-1.76)$ & $(0-0.17)$ \\
\hline Species richness & 14 & $(13-42)$ & $(15-42)$ & $(13-45)$ \\
\hline Diversity (Shannon-Wiener) & 14 & $(0.85-2.63)$ & $(0.34-2.33)$ & $(0.58-2.22)$ \\
\hline Evenness & 14 & $(0.33-0.82)$ & $(0.14-0.71)$ & $(0.17-0.75)$ \\
\hline
\end{tabular}

$N$, number of samples; Site S, site South; Site C, site Central; Site N, site North; Chl a, chlorophyll a. 

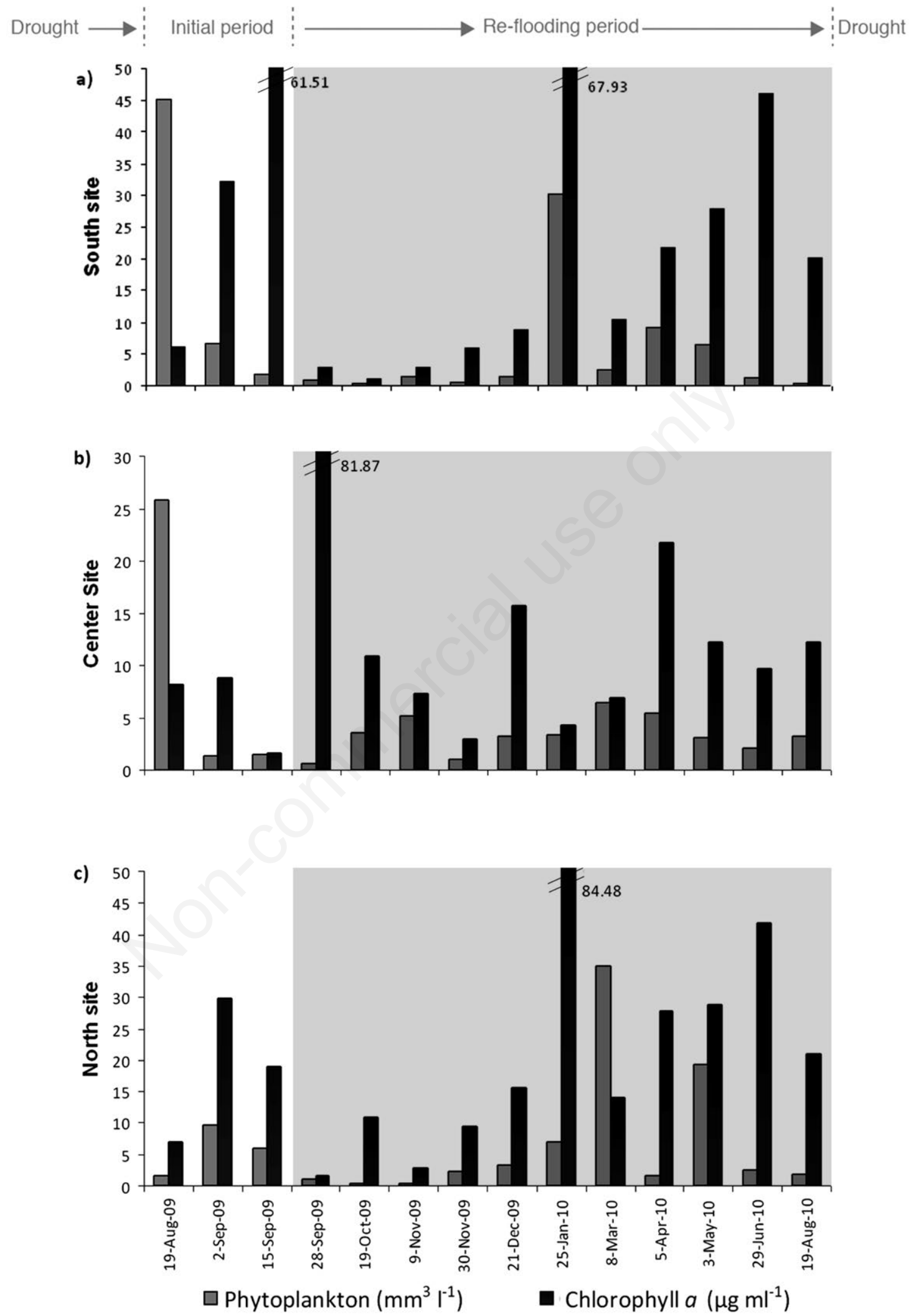

Fig. 4. Phytoplankton $>2 \mu \mathrm{m}$ biovolume (gray bars) and phytoplanktonic Chl $a$ concentration (black bars) in Los Coipos Lake during the study period (August 2009-August 2010). a) Site South. b) Site Central. c) Site North. The shaded background indicates the formation of a continuos shallow lake. 
that, whereas the three sites showed strong differences initially (site $\mathrm{N} v s$ site $\mathrm{S}$ : 0.33 ; site $\mathrm{N} v s$ site $\mathrm{C}$ : 0.09 , and site C vs site $\mathrm{S}: 0.04$ ), at the end of the study their community structure was notably more similar (site $\mathrm{N}$ vs site $\mathrm{S}$ : 0.63 ; site $\mathrm{N} v s$ site $\mathrm{C}: 0.79$ and site $\mathrm{C} v s$ site $\mathrm{S}: 0.84)$.

The eigenvalues of RDA axis $1(0.14)$ and axis 2 (0.07) accounted for $21.3 \%$ of the cumulative variance in the biovolume of 37 species. The species-environment correlations of RDA axes 1 and 2 were high (0.93 and 0.84 , respectively), and the first two axes accounted for $60.8 \%$ of the variance in the species-environment relationships. The factor that most affected the algal assem- blage was the presence of free-floating macrophytes (intraset correlation coefficient: -0.82) (Fig. 6). The second set of important factors were conductivity, presence of emergent macrophytes, PCSS, and water depth (intraset correlation coefficients: $0.80,-0.70,-0.68$ and -0.67 , respectively). Samples belonging to the initial period $(1,2$, 3 ) and $4 \mathrm{~S}$, clearly aggregated together in the lower-right side of the triplot characterized by high conductivity values. Most of the samples of the early re-flooding period (4 C, $4 \mathrm{~N}, 5,6,7,8$ ) aggregated in the upper-right side, whereas those of the late re-flooding period with further colonization by emergent and free-floating macrophytes
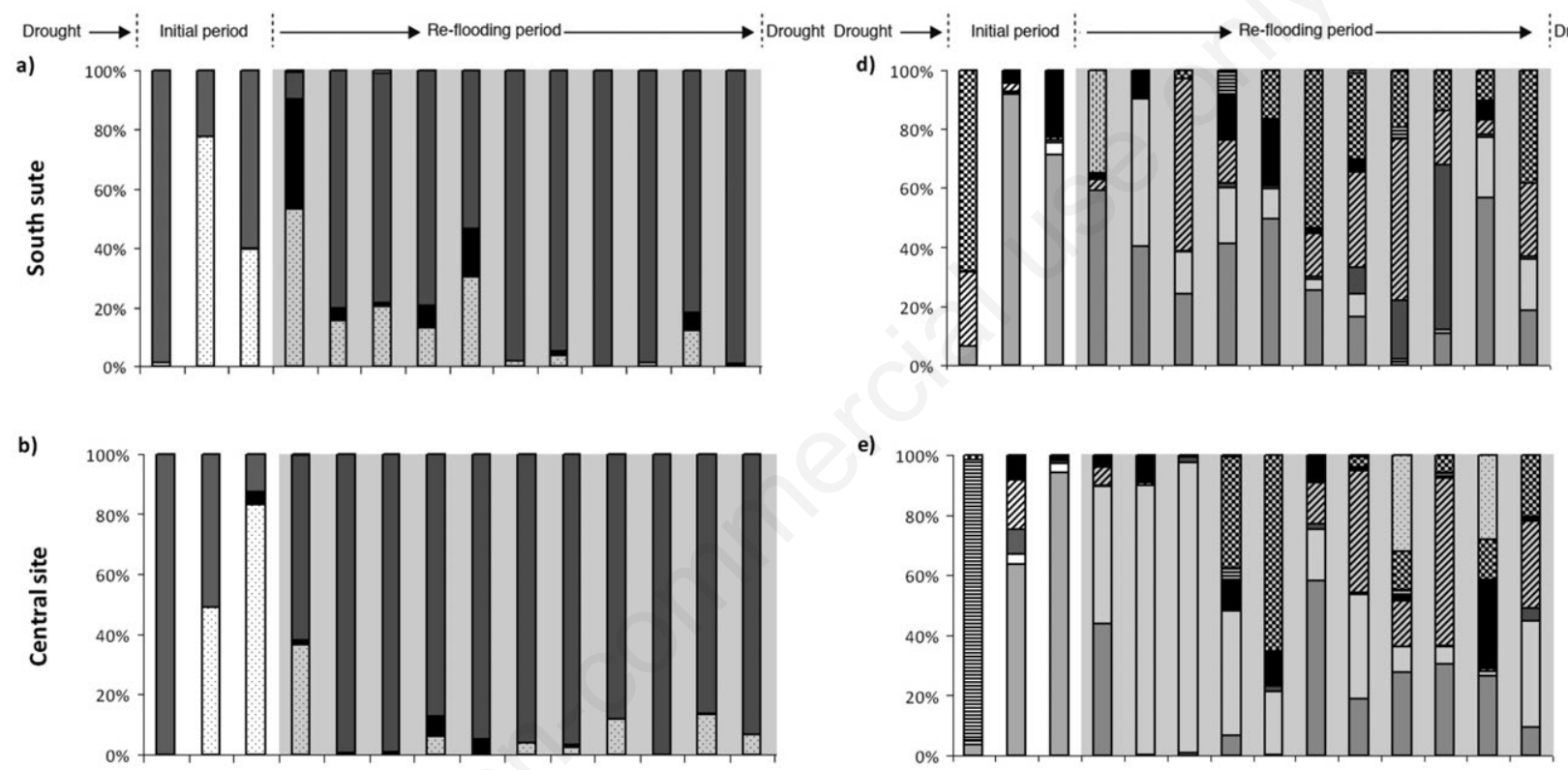

e)
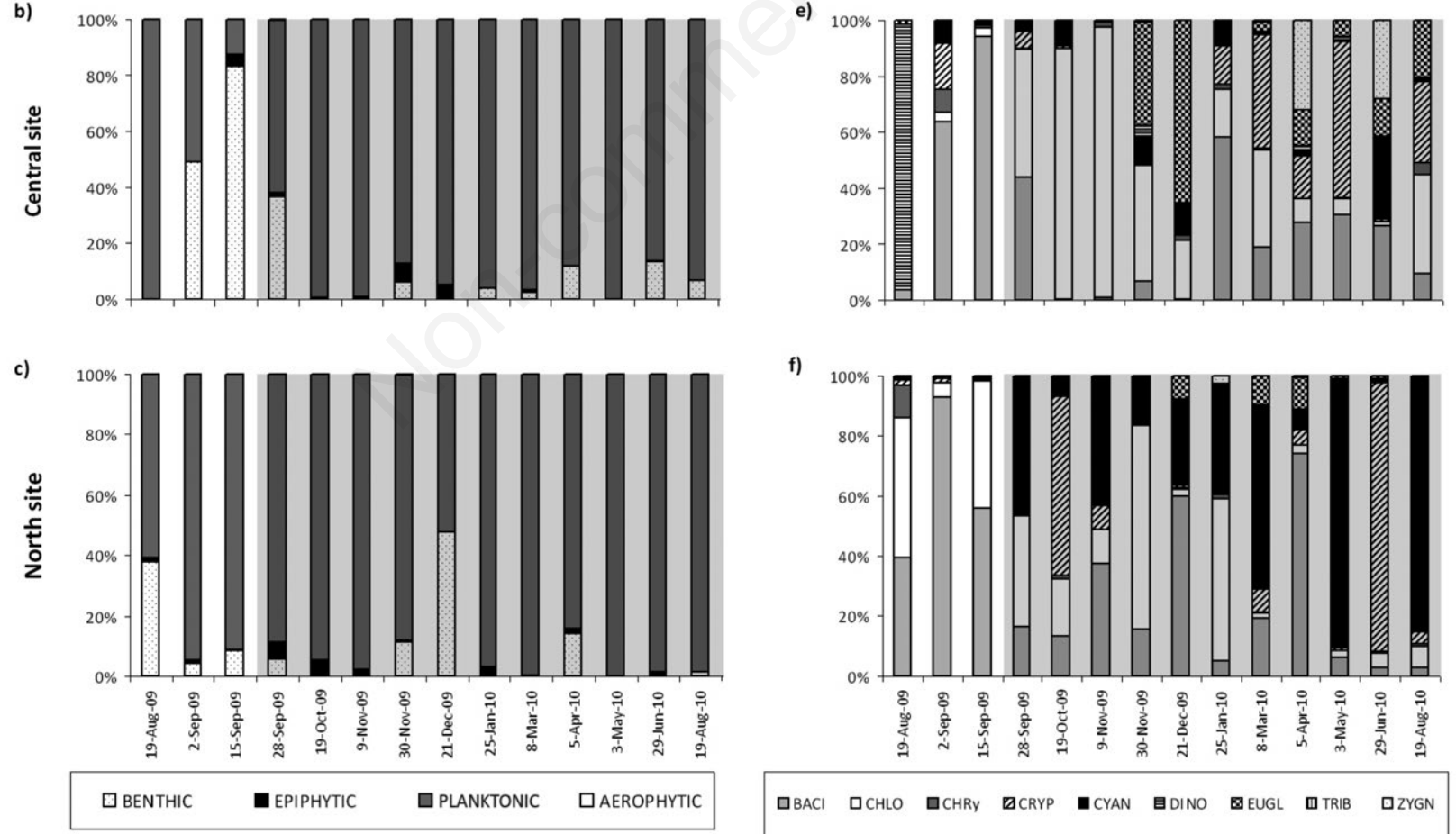

f)

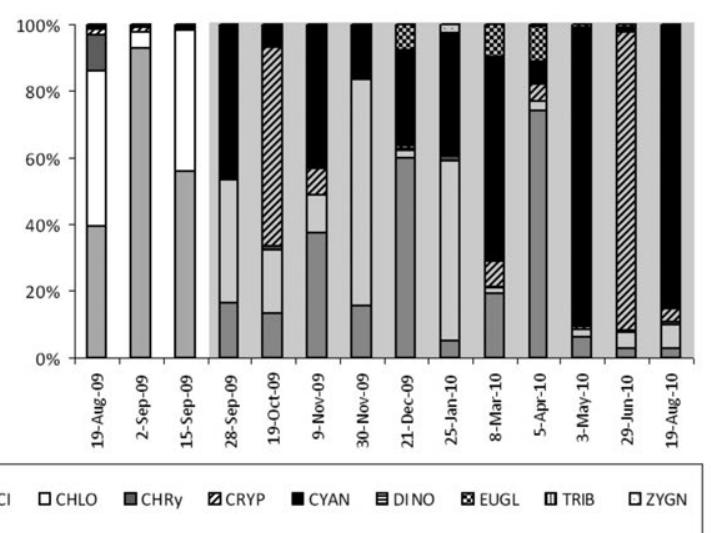

Fig. 5. a, b, c) Proportions of the habitats of cyanobacteria and algal classes to $>2 \mu$ m phytoplankton. d, e, f) Relative contribution of cyanobacteria and algal classes to $>2 \mu \mathrm{m}$ phytoplankton biovolume in Los Coipos Lake water column during the study period (August 2009-August 2010). a, d) Site South. b, e) Site Central. c, f) Site North. The shaded background indicates the formation of a continuous water body. BACI, Bacillariophyceae; CHLO, Chlorophyceae; CHRy, Chrysophyceae; CRYP, Cryptohyceae; CYAN, Cyanobacteria; DINO, Dinophyceae; EUGL, Euglenophyceae; TRIB, Tribophyceae; ZYGN, Zygnematophyceae. 
$(9,10,11,12)$ aggregated at the left side of the figure. The final period samples also aggregated together $(13,14)$ at the upper-left side. During that period, there was a complete macrophyte coverage of the shallow lake. It is worth mentioning that the sample 13 corresponding to the site C (13 C) did not have complete macrophyte coverage of its surface and is discrete from the rest of the samples of the final period.

\section{DISCUSSION}

The phytoplankton species structure and dynamics, as well as the dominant ecological functional groups, of a warm-temperate wetland subjected to drought/flood periods, responded to monthly water level shifts and to macrophyte cover fluctuations during an annual cycle. Starting from a dry state, the re-flooding and the gradual colonization by free-floating macrophytes (mainly Azolla filiculoides) of Los Coipos Lake, affected the water conditions and, as hypothesized, determined the phytoplankton assemblage in this wetland. The initial water depth registered during the studied drought/flood period was markedly lower than the one registered in previous studies (Fazio and O'Farrell, 2005). This fact is associated with the reduced precipitation in preceding years, resulting from the moderate and strong events of La Niña, which contributed to the drought of the region. May 2009 marked a new wet period that provoked the beginning of the re-flooding of the lake three months later (August 2009) when we initiated the study. In just 4 weeks the basin of the lake was re-filled. From June 2010 onwards, La Niña dominated again yielding to the gradual desiccation of this ecosystem. The effects of the shift between El
Niño and La Niña reflect the impact that these extreme hydrometeorological events may pose on wetlands.

During the studied annual cycle, both water level and macrophyte surface coverage fluctuated. Aquatic macrophytes play an important role in structuring communities in aquatic environments as they provide physical structure and increased habitat heterogeneity and complexity (Thomaz and Ribeiro da Cunha, 2010). Presence of macrophytes affects directly and indirectly the phytoplankton community by reducing water column mixing, limiting nutrient concentrations due to competition, reducing sediment resuspension and oxygenation of the water (Scheffer et al. 1993, 2003). In this respect, in our study the highest suspended solid concentrations in the water column coincided with the absence of vegetation. A profuse development of floating plants creates a stressful environment for phytoplankton, due to the low light intensity that impairs photosynthesis and growth, generating an imbalance between production and respiration (O'Farrell et al., 2009). As suggested for other warm nutrient-rich wetlands (Meerhoff $e t$ al., 2003; de Tezanos Pinto et al., 2007), reduced nutrient concentrations (mainly DIN in our study) and anoxic environments underneath the free-floating macrophyte cover may explain the low phytoplankton biovolume registered. Phytoplankton Chl $a$ concentration was typical of eutrophic and hypertrophic systems. As observed in other temporary water bodies (Cunha-Pereira et al., 2010), peaks of Chl $a$ occurred at varying times during the wet season. High values of Chl $a$ were found at the beginning stages of flooding. The high values of this pigment measured in summer 2010 (second peak) can be explained by a concentration effect of algae, as a result of the reduction in the water level of Los Coipos Lake. This pattern is repeatedly encountered in

Tab. 3. Dominant phytoplankton species in terms of biovolume recorded in Los Coipos Lake and their functional group classification, throughout the study period (August 2009-August 2010).

\begin{tabular}{|c|c|c|c|}
\hline & Site $\mathrm{S}$ & Site C & Site N \\
\hline $\begin{array}{l}\text { Initial pe } \\
\text { Species }\end{array}$ & $\begin{array}{c}\text { Euglena caudata, } \\
\text { Cryptomonas } \text { cf. obovata } \\
\text { Navicula cryptocephala var. veneta }\end{array}$ & Peridinium sp. & $\begin{array}{c}\text { Stephanocyclus meneghiniana, } \\
\text { Chlamydomonas spp. }\end{array}$ \\
\hline FG & $\mathrm{W} 1, \mathrm{Y}, \mathrm{T}_{\mathrm{B}}$ & $\mathrm{L}_{\mathrm{O}}$ & C, X1 \\
\hline $\begin{array}{l}\text { Early re- } \\
\text { Species }\end{array}$ & $\begin{array}{l}\text { Trachelomonas hispida, } \\
\text { Cryptomonas marsonii, } \\
\text { Nitzschia palea }\end{array}$ & $\begin{array}{l}\text { Cryptomonas cf. obovata, } \\
\text { Euglena sp., Oedogonium sp. }\end{array}$ & $\begin{array}{c}\text { Microcystis aeruginosa, } \\
\text { Microcystis } \mathrm{sp}, \\
\text { Stephanocyclus meneghiniana }\end{array}$ \\
\hline FG & W2, Y, D & $\mathrm{Y}, \mathrm{W} 1, \mathrm{~T}$ & $\mathrm{M}, \mathrm{L}_{\mathrm{M}}, \mathrm{C}$ \\
\hline $\begin{array}{l}\text { Late re-f } \\
\text { Species }\end{array}$ & $\begin{array}{l}\text { Cryptomonas cf. obovata, } \\
\text { Euglena sp., Stephanocyclus meneghiniana }\end{array}$ & $\begin{array}{l}\text { Cryptomonas cf. obovata, } \\
\text { Euglena sp., Mougeotia sp. }\end{array}$ & $\begin{array}{l}\text { Cryptomonas sp., } \\
\text { Microcystis smithii }\end{array}$ \\
\hline FG & Y, W1, C, & $\mathrm{Y}, \mathrm{W} 1, \mathrm{~T}$ & $\mathrm{Y}, \mathrm{L}_{\mathrm{M}}$ \\
\hline
\end{tabular}

Site S, site South; Site C, site Central; Site N, site North; FG, functional groups proposed by Reynolds et al. (2002) and reviewed by Padisák et al. (2009). 


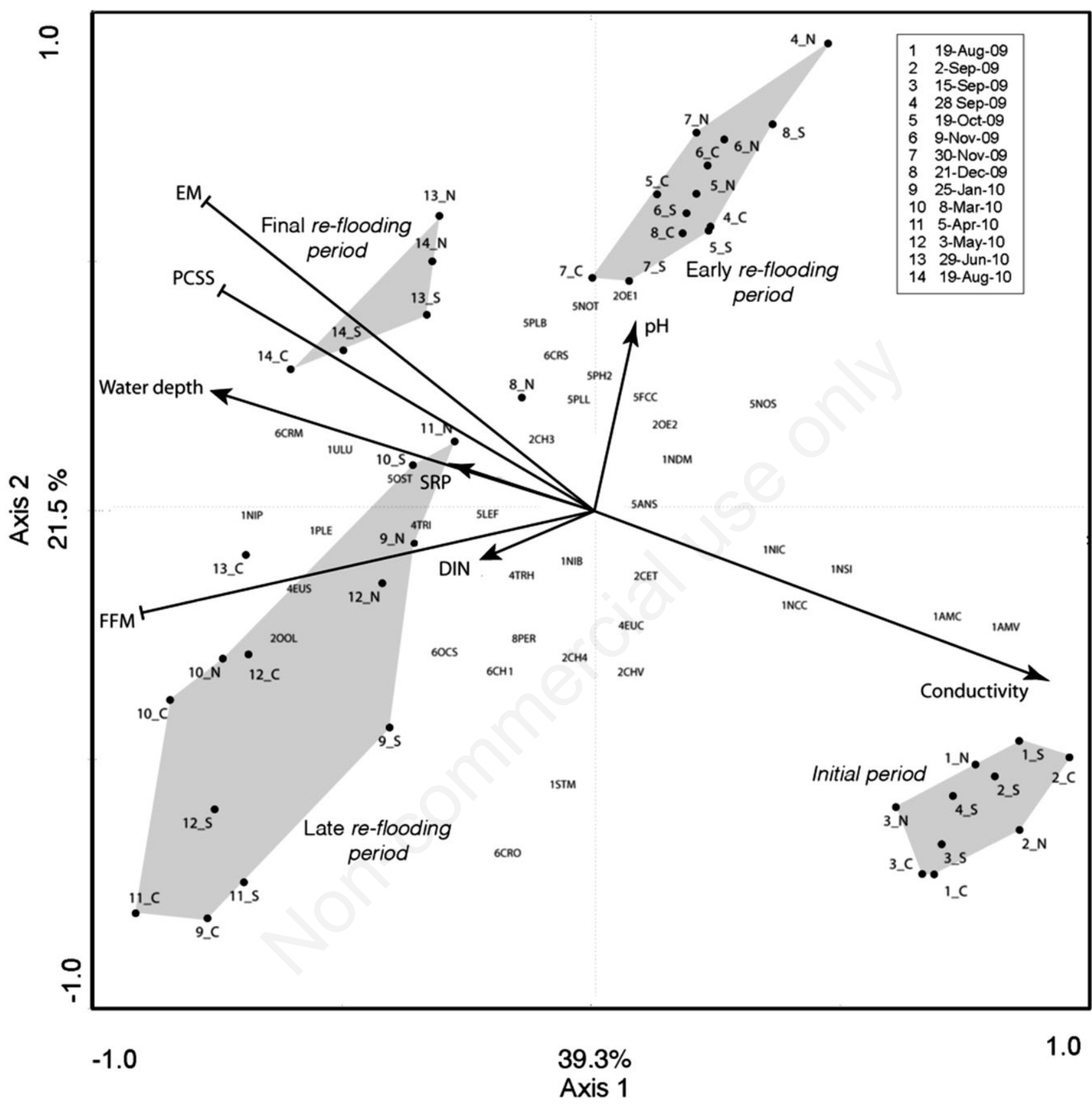

Fig. 6. RDA ordination plot of samples based on their phytoplankton attributes. Asterisks indicate significant environmental variables. Numbers (1-14) indicate sampling dates. S, site South; C, site Central; N, site North, DIN, dissolved inorganic nitrogen; SRP, soluble reactive phosphorus; PCSS, percentage macrophyte-cover of site surface; EM, emergent macrophytes; FFM, free-floating macrophytes; 1AMC, Amphora coffeaeformis; $1 \mathrm{AMV}$, Amphora veneta; $1 \mathrm{NCC}$, Navicula cryptocephala var. cryptocephala; $1 \mathrm{NIB}$, Nitzschia brevissima; 1NIC, Nitzschia capitellata; 1NDM, Nitzschia dissipata var. media; 1NIP, Nitzschia palea; 1NSI, Nitzschia sigma; 1PLE, Pleurosigma cf. elongatum; 1STM, Stephanocyclus meneghiniana; 1ULU, Ulnaria ulna; 2CH3, Chlamydomonas sp.3; 2CH4, Chlamydomonas sp.4; 2CET, Chlamydomonas sp.5; 2CHV, Chlorella vulgaris; 2OE1, Oedogonium sp.1; 2OE2, Oedogonium sp.2; 2OOL, Oocystis lacustris; 2PAM, Pandorina morum; 4EUC, Euglena caudata; 4EUS, Euglena sp.; 4TRH, Trachelomonas hispida; 4TRI, Trachelomonas intermedia; 5ANS, Anabaena sp.; 5LEF, Leptolyngbya fragilis; 5MIC, Microcystis sp.; 5MIA, Microcystis aeruginosa; 5MIS, Microcystis smithii; 5NOS, Nodularia spumigena; 5NOT, Nostoc sp.; 5OST, Oscillatoria tenuis; 5PH2, Phormidium sp.2; 5PLB, Planktolyngbya brevicellularis; 5PLL, Planktolyngbya limnetica; 5FCC, filamentous Cyanophyceae; 6CRM, Cryptomonas marsonii; 6CRO, Cryptomonas cf. obovata; 6CRS, Cryptomonas sp.; 6CH1, Chrysophyceae sp.1; 6OCS, Ochromonas cf. viridis; 8PER, Peridinium sp. 
other Pampean shallow lakes close to being dry (Sosnovsky and Quiros, 2006), as well as in wetlands from other latitudes (Naselli-Flores and Barone, 2012). Small $(<2 \mu \mathrm{m})$ fast-growing picophytoplankton is generally well represented in the phytoplankton community in shallow lakes of differing latitudes (Bell and Kalff, 2001; Callieri, 2007) and our results agree with this. Picocyanobacteria were onefold greater than picoeukaryotic algae, which is a common finding in aquatic ecosystems worldwide (Callieri, 2007). Picoeukaryotic algae contribution is known to increase with decreasing light availability (Søndergaard, 1991; Callieri, 2007; Izaguirre et al., 2010; Silvoso et al., 2011). In line with these findings, with the augmentation of Azolla filiculoides development in Los Coipos shallow lake, and concomitant reduction in light availability beneath the free-floating macrophyte cover, an increase in picoeukaryotic algae was also observed. Marked decreases in light penetration under profuse Azolla sp. coverage was measured in a nearby wetland (Reserva Natural Otamendi, Buenos Aires, Argentina) revealing that up $98 \%$ of total incident light was reduced under this situation (de Tezanos Pinto et al., 2007).

As for the $>2 \mu \mathrm{m}$ phytoplankton, statistical analyses evidenced the importance of environmental factors in shaping its assemblage during the initial and re-flooding periods of our study. In particular, changes in the depth of the water column, conductivity and development of an emergent and free-floating macrophyte cover affected the phytoplankton composition in Los Coipos Lake the most. Reynolds (2006) stressed that in truly novel planktonic habitats, the first colonists have to arrive de novo, and species that become initially abundant either arrive in strength or grow rapidly, or do both. Some unicellular organisms that have high growth rates are recognized as pioneer species. In this respect, following the functional group (FG) classification (after Reynolds et al., 2002 and reviewed by Padisák et al., 2009) we encountered small Chlamydomonas spp. (X1 FG, Chlorophyceae) and Ochromonas cf. viridis (X2 FG, Chrysophyceae) that achieved relatively high abundances in developing pools in the initial period of our study. It is worth mentioning that Ochromonas cf. viridis dominance was not expressed in terms of biovolume due to their relatively small size. These (X1 and X2 FG) are typical small fast-growing algae. We also found high relative proportions of euglenoids; it is recognized that the drying phase of temporary water bodies is characterized by a very diverse assemblage mainly formed by euglenoids (W1 and W2 FG) often accompanied by dinoflagellates $\left(\mathrm{L}_{\mathrm{o}} \mathrm{FG}\right)$ because they generally persist to the point of complete desiccation of the pond (Naselli-Flores and Barone, 2012). The dominance of benthic Bacillariophyceae $\left(\mathrm{C}\right.$ and $\left.\mathrm{T}_{\mathrm{B}} \mathrm{FG}\right)$ during the initial period was favored by the absence of macrophytes as it is recognized that heavy diatoms rely on tur- bulence to counteract sedimentation (Padisák et al., 2003; Allende et al., 2009; Stević et al., 2013).

In the re-flooding period, the new conditions triggered by the insipient formation of the continuous shallow lake allowed the further colonization and growth of planktonic algae as reflected by the replacement of benthic algae (mostly dominant in initial period) by pelagic ones. The dominance of Cryptophyceae on different sampling dates, can be explained by the fact that Cryptomonas marsonii and $C$. cf. obovata (Y FG), are typical mixotrophic flagellated organisms that can withstand occasional nitrogen and light limitation, as they can ingest bacteria (Tranvik et al., 1989; Jones, 2000; Urabe et al., 2000; Sinistro et al., 2007; Unrein et al., 2007; Allende et al., 2009). This fact, and the capacity to migrate vertically in order to reach optimum light condition, allowed them to remain in the water column during the whole phytoplankton succession, and to reach a greater contribution when macrophyte cover was more profuse and/or DIN concentration was low in the late re-flooding period. Dominance of Cyanobacteria on certain occasions was related to the establishment of macrophytes, which results in low light conditions and enhanced physical stability of the water column. In this sense, Olding et al. (2000) stated that some cyanobacteria species are sensitive to vertical mixing. Also, it is known that some species of this group are able to grow at low light intensities and warm temperatures (Chorus and Bartram, 1999; Carey et al., 2012). In particular, Planktolynbya limnetica (S1 FG) is tolerant of deficient light conditions (Reynolds et al., 2002) and Microcystis ( $\mathrm{M}$ or $\mathrm{L}_{\mathrm{M}} \mathrm{FG}$ ) is a fast migrating genus that may benefit in stratified conditions by gaining a competitive advantage over other non-migrating or slow-migrating phytoplankton (Carey et al., 2012). The commonest species of Chlorophyceae were nanoflagellated Chlamydomonas spp. and Chlorella vulgaris (both $\mathrm{X} 1$ ), which are both typically small pioneer organisms and were present throughout the study. These genera are amongst the major airborne algae (Happey-Woods, 1988, and references therein; Genitsaris et al., 2011) and they can rapidly colonize standing waters if the nutrient conditions are appropriate. However, due to their small size their contribution to the total biovolume was not significant. Different authors have suggested that different strategies adopted by phytoplankton are related to morphological (size, shape, motility) and physiological (nutritional requirements) differences (Reynolds et al., 2002; Kamenir et al., 2004; Carey et al., 2012). In this sense under the extreme scenario encountered at the end of our study, which included reduced light availability and vertical mixing, species belonging to functional groups that have adaptations to withstand these harsh conditions, dominated the phytoplankton assemblage. Among them, typical flagellated mixotrophic algae - Euglena caudata (W1 FG), 
Ochromonas sp. (X2 FG) and Cryptomonas cf. obovata, Cryptomonas sp. and Cryptomonas marsonii (all Y FG) and Cyanobacteria - Planktolyngbya limnetica (S1 FG) and Microcystis smithii ( $\left.\mathrm{L}_{\mathrm{M}} \mathrm{FG}\right)$ - that are tolerant to low light conditions and are able to regulate buoyancy. As macrophytes grew during the re-flooding period epiphytic algae were also encountered in the water column. Detachment of these algae from their substrata as a result of wind action in low water periods affects species richness in the water column. Thus, during early re-flooding period, the increase in water depth and greater availability of substrata for epiphytes contributed to the augmenting of phytoplankton species richness. When conditions were more homogeneous and the whole shallow lake was covered by free-floating plants in the late re-flooding period, the conditions provoked a reduction in species richness as suggested for other freshwater ecosystems under similar conditions (Scheffer et al., 2006). Values of the SIMI index revealed that initially the three sites (pools) strongly differed in their phytoplankton species structure showing a relatively high spatial heterogeneity, probably due to the fact that different resting stages of colonists were able to develop in the nascent community of the new planktic habitat in Los Coipos Lake. However, the relatively high SIMI index observed among sites at the end of the study evidenced that the structure of the phytoplankton assemblage was forced not only by the water level increase, but also by the strong effect imposed by the complete freefloating macrophyte cover.

As stated above, under the conceptual model of Goldsborough and Robinson (1996) for algae in wetlands, we recognize that during the drought/flood period studied, Los Coipos Lake was initially in a dry state. In our study, after the re-flooding a shallow lake was formed that ended-up being completely covered not by metaphyton as expected for the sheltered state, but rather, by emergent and free-floating plants. In this regards, the phytoplankton community was exposed to some of the environmental conditions prevalent under the sheltered state, such as presence of aquatic macrophytes, reduced light penetration, medium water level and stability of the water column. However, it must be pointed out that in this wetland it was provoked by the presence of aquatic plants and not metaphytic algae.

In conclusion, our results provide evidence that changes in water level and the complete surface coverage by free-floating macrophytes were the main determinants of the structure and dynamics of the phytoplankton assemblage. In particular, the functional group approach revealed that the phytoplankton assemblage responded to rapid water level shifts (mainly represented by small fastgrowing X1 and X2) and to the changes imposed in the water conditions as a result of the presence of a total freefloating macrophyte cover (W1, $\left.\mathrm{T} \mathrm{y}_{\mathrm{M}}\right)$.

\section{ACKNOWLEDGMENTS}

This work was financed by a grant from the University of Buenos Aires UBACyT X838. We thank Ruben Lombardo and Soledad Fontanarrosa for statistical advice, Federico Posadas for figures editing, and Enrique Rodríguez and Irina Izaguirre for valuable comments on the manuscript. We are grateful to the Reserva Ecológica Costanera Sur (Buenos Aires, Argentina) for the logistic support and especially to Horacio Sirolli, Lorena Zapata, Amancay Mamani and Armando Renella for their cooperation in field campaigns. We also thank Dr. Itzick Vatnick for language revision.

Thanks are due to two unknown reviewers for their useful comments on the manuscript.

\section{REFERENCES}

Allende L, Tell G, Zagarese HE, Torremorell A, Pérez G, Bustingorry J, Escaray R, Izaguirre I, 2009. Phytoplankton and primary production in clear-vegetated, inorganic-turbid and algal-turbid shallow lakes from Pampa Plain (Argentina). Hydrobiologia 624:45-60.

Angeler DG, Alvarez-Cobelas M, Rojo C, Sanchez-Carrillo S, 2010. Phytoplankton community similarity in a semiarid floodplain under contrasting hydrological connectivity regimes. Ecol. Res. 25:513-520.

APHA, 2005. Standard Methods for the Examination of Water and Wastewater. American Public Health Association: 1193 pp.

Bell T, Kalff J, 2001. The contribution of picophytoplankton in marine and freshwater systems of different trophic status and depth. Limnol. Oceanogr. 46:1243-1248.

Bucak T, Saraoğlu E, Leví E, Nihan Tavşanoğlu Ü, Idil Çakiroğlu A, Jeppensen E, Beklioğlu M, 2012. The influence of water level on macrophyte growth and trophic interactions in eutrophic Mediterranean shallow lakes: a mesocosm experiment with and without fish. Freshwater Biol. 57:1631-1642.

Callieri C, 2007. Picophytoplanton in freshwater ecosystems: the importance of small-sized phototrophs. Freshwater Rev. $1: 1-28$.

Carey C, Ibelings B, Hoffmann E, Hamilton D, Brookes J, 2012. Eco-physiological adaptations that favour freshwater cyanobacteria in a changing climate. Water Res. 46:1394-1407.

Chorus I, Bartram J, 1999. Toxic cyanobacteria in water: a guide to public health significance, monitoring and management. Chapman \& Hall: 400 pp.

Cunha-Pereira H, Allot N, Coxon, C, 2010. Are seasonal lakes as productive as permanent lakes? A case study from Ireland. Can. J. Fish. and Aq. Sc. 67:1291-1302.

Davis TJ, Blasco D, Carbonell M, 1996. [Manual de convención Ramsar. Una Guía Internacional].[Book in Spanish]. Oficina de la Convención Ramsar, Dirección General de la Conservación de la Naturaleza, Ministerio de Medio Ambiente, Spain.

De Stasio BT, 1990. The role of dormancy and emergence patterns in the dynamics of a freshwater zooplankton community. Limnol. Oceanogr. 35:1079-1090.

de Tezanos Pinto P, Allende L, O'Farrell I, 2007. Influence of free-floating plants on the structure of a natural phytoplank- 
ton assemblage: an experimental approach. J. Plankton Res. 29:47-56.

Elber F, Schanz F, 1989. The causes of change in the diversity and stability of phytoplankton communities in small lakes. Freshwater Biol. 21:237-251.

Ettl H, 1978. [Xanthophyceae], p. 1-530. In: H. Ettl, J. Gerloff and H. Heynig (eds.), Süsswasserflora von Mitteleuropa. 3].[Book in German]. Fischer Verlag.

Fazio A, O'Farrell I, 2005. Phytoplankton and water quality in a shallow lake: a response to secondary salinization (Argentina). Wetlands 25:531-541.

Genitsaris S, Moustaka-Gouni M, Kormas KA, 2011. Airborne microeukaryote colonists in experimental water containers: diversity, succession, life histories and established food webs. Aq. Microbial Ecol. 62: 139-152.

Granado DC, Henry R, 2014. Phytoplankton community response to hydrological variations in oxbow lakes with different levels of connection to a tropical river. Hydrobiologia 721:223-238.

Goldsborough LG, Robinson GGC, 1996. Pattern in Wetlands, p. 78-117. In: R.J. Stevenson, M.L. Bothwell and R.L. Lowe (eds.), Algal ecology. Freshwater benthic ecosystems. Academic Press.

Gottlieb AG, Richards JH, Gaiser EE, 2005. Effects of desiccation duration on the community structure and nutrient retention of short and long hydroperiod Everglades periphyton mats. Aquat. Bot .82:99-112.

Happey-Wood CM, 1988. Ecology of freshwater planktonic green algae, p. 175-226. In: C.D. Sandgren (ed.), Growth and reproductive strategies of freshwater phytoplankton. Cambridge University Press.

Hillebrand H, Dürselen CD, Kirschtel D, Pollingher U, Zohary T, 1999. Biovolume calculation for pelagic and benthic microalgae. J. Phycol. 35:403-424.

Hüber-Pestalozzi G, 1941. [Chrysophyceen], p. 1-247. In: A. Thienemann (ed.), [Die Binnengewässer. Das Phytoplankton des Süsswassers.16].[Book in German]. Nägele and Obermiller.

IPCC (Intergovernmental Panel on Climate Change), 2007. Fourth Assessment Report. http://www.ipcc.ch/. Accessed 3 March 2010.

Izaguirre I, Pizarro H, de Tezanos Pinto P, Rodriguez P, O’Farrel I, Unrein F, Gasol JM, 2010. Macrophyte influence on the structure and productivity of photosynthetic picoplankton in wetlands. J. Plank. Res. 32:221-238.

Javornicky P, 2003. Taxonomic notes on some freshwater planktonic Cryptophyceae based on light microscopy. Hydrobiologia 502:271-283.

Jentsch AJ, Kreyling J, Beierkuhnlei C, 2007. A new generation of climate-change experiments: events, not trends. Front. Ecol. Environm. 5:365-374.

Jones RI, 2000. Mixotrophy in planktonic protist: an overview. Freshwater Biol. 45:219-226.

Jeppesen E, Søndergaard M, Meerhoff M, Lauridsen YL, Jensen JP, 2007. Shallow lake restoration by nutrient loading reduction - some recent findings and challenges ahead. Hydrobiologia 584:239-252.

Kamenir Y, Dubinsky Z, Zohary T, 2004. Phytoplankton size structure stability in a meso-eutrophic subtropical lake. Hydrobiologia 520:89-104.
Kemp WM, Puskaric S, Faganeli A, Smith E, Boynto W, 1999. Pelagic-benthic coupling and nutrient cycling, p. 295-339. In: T. Malone, A. Malej, L. Harding, N. Smodlaka and R. Turner (eds.), Ecosystems at the land-sea margin: drainage basin to coastal sea. American Geophysical Union.

Komárek J, Anagnostidis K, 1999. [Cyanoprokaryota. 1. Chroococcales], p. 1-548. In: H. Ettl, J. Gerloff, H. Heynig and D. Mollenhauer (eds.), [Süsswasserflora von Mitteleuropa 19/1].[Book in German]. Gustav Fischer Verlag.

Komárek J, Anagnostidis K, 2005. [Cyanoprokaryota. 2. Oscillatoriales], p. 1-759. In: B. Büdel, L. Krienitz , G. Gärtner and M. Schagerl (eds.), [Süsswasserflora von Mitteleuropa 19/2].[Book in German]. München.

Komárek J, Fott B, 1983. [Chlorophyceae, Chlorococcales], p. 1-1044. In: H.J. Elster and W. Ohle (eds.), [Die Binnengewässer. Das Phytoplankton des Süsswasser, 16].[Book in German]. Nägele and Obermiller.

Krammer K, Lange-Bertalot H, 1986. [Bacillariophyceae. 1. Naviculaceae], p. 1-876. In: H. Ettl, J. Gerloff, H. Heying and D. Mollenhauer (eds.), [Süsswasserflora von Mitteleuropa].[Book in German]. Fischer.

Krammer K, Lange-Bertalot H, 1988. [Bacillariophyceae. 2. Bacillariaceae, Epithemiaceae, Surirellaceae], p. 1-596. In: H. Ettl, J. Gerloff, H. Heying and D. Mollenhauer (eds.), [Süsswasserflora von Mitteleuropa].[Book in German]. Fischer.

Krammer K, Lange-Bertalot H, 1991a. [Bacillariophyceae. 3. Centrales, Fragilariaceae, Eunotiaceae], p. 1-576. In: H. Ettl, J. Gerloff, H. Heying and D. Mollenhauer (eds.), [Süsswasserflora von Mitteleuropa].[Book in German]. Fischer.

Krammer K, Lange-Bertalot H, 1991b. [Bacillariophyceae 4. Achnanthaceae, kritische Ergänzungen zu Navicula (Lineolatae) und Gomphonema Gesamtliteraturverzeichnis Teil 1-4], p. 1-437. In: H. Ettl, J. Gerloff, H. Heying and D. Mollenhauer (eds.), [Süsswasserflora von Mitteleuropa].[Book in German]. Fischer.

Lake PS, 2011. Drought and aquatic ecosystems: effects and responses. Wiley \& Blackwell: 381 pp.

Lange-Bertalot H, 2001. Diatoms of Europe. 2. ARG Gantner Verlag: 526 pp.

Leibold MA, Norberg J, 2004. Biodiversity in metacommunities: plankton as complex adaptive systems? Limnol. Oceanogr. 49:1278-1289.

Lorenzen CJ, 1967. Determination of chlorophyll and pheopigments: spectrophotometric equations. Limnol. Oceanogr. 12:343-346.

Magurran AE, 1988. Ecological diversity and its measurements. Princeton University Press: 179 pp.

Meerhoff M, Mazzeo N, Moss B, Rodriguez Gallego L, 2003. The structuring role of free floating versus submerged plants in a subtropical shallow lake. Aquat. Ecol. 37:377-391.

Meerhoff M, Clemente JM, Teixeira de Mello F, Iglesias C, Pedersen AR, Jeppesen E, 2007. Can warm climate-related structure of littoral predator assemblies weaken the clear water state in shallow lakes? Global Change Biol. 13:1888-1897.

Metzeltin D, García-Rodriguez F, 2003. [Las diatomeas uruguayas].[Book in Spanish]. DI.R.A.C.: 208 pp.

Naselli-Flores L, Barone R, 2005. Water-level fluctuations in Mediterranean reservoirs: setting a dewatering threshold as a management tool to improve water quality. Hydrobiologia 548:85-99. 
Naselli-Flores L, Barone R, 2012. Phytoplankton dynamics in permanent and temporary Mediterranean waters: is the game hard to play because of hydrological disturbance? Hydrobiologia 701:219-233.

Neustupa J, Cerná K, Stástný J, 2011. The effects of aperiodic desiccation on the diversity of benthic desmid assemblages in a lowland peat bog. Biodivers. Conserv. 20:1695-1711.

Nusch EA,1980. Comparison of different methods for chlorophyll and paeopigment determination. Adv. Limnol. 14:14-36.

O'Farrell I, de Tezanos Pinto P, Rodriguez PL, Chaparro G, Pizarro HN, 2009. Experimental evidence of the dynamic effect of free-floating plants on phytoplankton ecology. Freshwater Biol. 54:363-375.

Olding D, Hellebust A, Douglas M, 2000. Phytoplankton community composition in relation to the water quality and water-body morphometry in urban lakes, reservoirs, and ponds. Can. J. Fish. Aquat. Sci. 57:2163-2174.

Padisák J, Soróczki-Pinter É, Rezner Z, 2003. Sinking properties of some phytoplankton shapes and the relation of form resistance to morphological diversity of plankton: an experimental study. Hydrobiologia 500:243-257.

Padisák J, Crossetti L, Naselli-Flores L, 2009. Use and misuse in the application of the phytoplankton functional classification: a critical review with updates. Hydrobiologia 621:1-19.

Pielou EC, 1966. The measurement of diversity in different types of microbial collections. Biologist 13:131-144.

Prescott GW, Croasdale HT, Vinyard WC, 1975. A synopsis of North American Desmids. II. Desmidiaceae: Placodermae, section 1. Nebraska Univ. Press: 275 pp.

Prescott GW, Croasdale HT, Vinyard WC, 1977. A synopsis of North American Desmids. II. Desmidiaceae: Placodermae, section 2. Nebraska Univ. Press: 413 pp.

Prescott GW, Croasdale HT, Vinyard WC, Bicuado CE, 1981. A synopsis of North American Desmids. II. Desmidiaceae: Placodermae, section 3. Nebraska Univ. Press: 720 pp.

Reynolds C, Huszar V, Kruk C, Naselli-Flores L, Melo S, 2002. Towards a functional classification of the freshwater phytoplankton. J Plankton Res. 24:417-428.

Reynolds CS, 2006. Community assembly in the plankton: pattern, process and dinamics, p. 302-386. In: C.S. Reynolds (ed.) Ecology of phytoplankton. Cambridge University Press.

Rojo C, Alvarez-Cobelas M, Benavent-Corai J, Barón-Rodríguez MM, Rodrigo MA, 2012. Trade-offs in plankton species richness arising from drought: insights from longterm data of a National Park wetland (central Spain). Biodivers. Conserv. 21:2453-2476.

Scheffer M, Hosper SH, Meijer ML, Moss B, Jeppesen E, 1993. Alternative equilibria in shallow lakes. Trends Ecol. Evol. 8:275-279.

Scheffer M, Szarbó S, Gragnani A, van Nes E, Rinaldi S, Kautsky N, Norberg J, Roijackers RM, Franken RJ, 2003. Floating plant dominance as stable state. P. Natl. Acad. Sci. USA 100:4040-4045.

Scheffer M, van Geest JG, Zimmer K, Jeppesen E, Søndergaard M, Butler MG, Hanson MA, S. Declerck S, De Meester L, 2006. Small habitat size and isolation can promote species richness: second-order effects on biodiversity in shallow lakes and ponds. Oikos 112:227-231.

Servicio Meteorológico Nacional, 2012. Accessed on: 3 May 2012. Available from: http://www.smn.gov.ar/

Silvoso J, Izaguirre I, Allende L, 2011. Picoplankton structure in clear and turbid eutrophic shallow lakes: a seasonal study. Limnologica 41:181-190.

Sinistro R, Izaguirre I, Asikian V, 2007. Experimental study on the microbial plankton community in a South American wetland (Lower Paraná River Basin), and the effect of the light deficiency due to floating macrophytes. J. Plankton Res. 28:753-768.

Skinner R, Sheldon F, Walker KF, 2001. Propagules in dry wetland sediments as indicators of ecological health: effects of salinity. River Res. Appl. 17:191-197.

Søndergaard M, 1991. Phototrophic picoplankton in temperate lakes: seasonal abundance and importance along a trophic gradient. Int. Rev. Ges. Hydrobiol. 76:505-522.

Sosnovsky A, Quirós R, 2006. [El estado trófico de pequeñas lagunas pampeanas, su relación con la hidrología y el uso de la tierra].[Article in Spanish]. Ecol. Austral (online) 16:2.

Starmach K, 1985. [Chrysophyceae und Haptophyceae], p. 1594. In: H. Ettl, J. Gerloff, H. Heynig and D. Mollenhauer (ed.), [Süsswasserflora von Mitteleuropa, Band 1].[Book in German]. Gustav Fischer Verlag.

Stević F, Mihaljević M, Špoljarić D, 2013. Changes of phytoplankton functional groups in a floodplain lake associated with hydrological perturbations. Hydrobiologia 709:143-158.

Stumpf RP, 1992. Remote sensing of water clarity and suspended sediments in coastal waters, P. SPIE 1930:293-305.

Sun J, Liu D, 2003. Geometric models for calculating cell biovolume and surface area for phytoplankton. J. Plankton Res. 11:1331-1346.

Tell G, Conforti V, 1986. Euglenophyta pigmentadas de la Argentina. Biblioth. Phycol. 75:1-301.

ter Braak C, Smilauer P, 2002. CANOCO Reference Manual and Canocodraw for Windows User's Guide: Software for Canonical Community Ordination, ver. 4.5. Microcomputer Power, Ithaca: 500 pp.

Thomaz SM, Ribeiro da Cunha E, 2010. The role of macrophytes in habitat structuring in aquatic ecosystems: methods of measurement, causes and consequences on animal assemblages' composition and biodiversity. Act. Limnol. Bras. 22:218-236

Timmermann A, Oberhuber J, Bacher A, Esch M, Latif M, Roeckner E, 1999. Increased El Niño frequency in a climate model forced by future greenhouse warming. Nature 398:694-697.

Tranvik LJ, Porter KG, Sieburth JM, 1989. Occurrence of bacterivory in Cryptomonas, a common freshwater phytoplankter. Oecologia 78:473-476.

Unrein F, Massana R, Alonso-Sáez L, Gasol JM, 2007. Significant year-round effect of small mixotrophic flagellates on bacterioplankton in an oligotrophic coastal system. Limnol. Oceanogr. 52:456-469.

Urabe J, Gurung TB, Yoshida T, Sekino T, Nakanishi M, Maruo M, Nakayama E, 2000. Diel changes in phagotrophy by Cryptomonas in Lake Biwa. Limnol. Oceanogr. 45:1558-1563.

Utermöhl M, 1958. [Zur Vervollkomnung der quantitativen Phytoplankton-Methodik].[Article in German]. Mitt. Int. Verein. Theoret. Angew. Limnol. 9:1-38.

Venrick EL, 1978. How many cells to count?, p. 167-180. In: A. Sournia (ed.) Phytoplankton Manual. UNESCO.

Zalocar de Domitrovic Y, Maidana NI, 1997. Taxonomic and ecological studies of the Paraná River diatom flora (Argentina). Bibliotheca Diatomatologica 34. Cramer: 122 pp. 